\title{
The Integration of Fuzzy-ISM, Fuzzy-AHP, and Fuzzy-MICMAC Approach under Trapezoid Fuzzy Linguistic to Analyze Enablers of The Logistics Outsourcing Relationship: Mekong Delta, Vietnam Rice Supply Chain Context.
}

\author{
Nguyen Thang Loi $^{1}$, H.T.T Hoa ${ }^{2}$, P.D.T.Anh ${ }^{1}$, N.D.Khoi ${ }^{1}$, N.T.K.My ${ }^{1}$, N.T.Luan ${ }^{1}$ \\ ${ }^{1}$ FPT University, School of Business. \\ ${ }^{2} \mathrm{Ho}$ Chi Minh City University of Transport
}

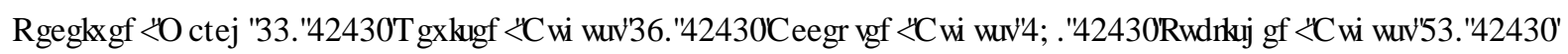

\begin{abstract}
The purpose of this paper is to analyze the effects of the factors and determine the importance of these factors to the LO relationship with the desire to improve the efficiency in logistics activities of the supply chain. An integrated approach including Fuzzy Interpretation Structure Model (FISM), Fuzzy Cross-Impact Matrix Multiplication Applied to Classification (FMICMAC) analysis, Fuzzy Analytic Hierarchy Process (FAHP) is structured in reaching this purpose. Specifically, the impact of factors on the LO relationship will be determined through the FISM-FMICMAC method, then FAHP will use the results from this FISM-FMICMAC analysis step to perform the determination of the level of importance of contributing factors to the LO relationship. The fuzzy number formats of this paper are all in trapezoidal format. To evaluate the proposed framework, a typical example of logistics activity in the Mekong Delta Rice Supply Chain (SuC) was selected. The results have shown the impact level of 14 factors on the $\mathrm{LO}$ relationship under 4 clusters (Dependent, Linkage, Independent Autonomous). Finally, only the 10 most outstanding of the 14 factors were used to conduct FAHP analysis to find the global weightages which contribute to the $\mathrm{LO}$ relationship by each factor.
\end{abstract}

Keywords: Fuzzy-AHP, Fuzzy-ISM-MICMAC, Relationships, Rice Supply Chain, Third-party logistics service providers, Trapezoidal linguistic.

\section{INTRODUCTION}

Although it is one of the countries with the top trade-to-GDP ratio in the world, specifically over $170 \%$, Vietnam's logistics have been also incurred costs more than $20 \%$ of GDP, which is belonging to the highest line in the world. [1-2]

Recognizing the great importance and efficiency of logistics services, Vietnam has focused on building a legal, policy framework, and in particular, outsourced logistics services have been expanded through the applicable preparatory regulations. use in the coming time. Therefore, the enterprises prefer outsourcing LSP for their logistics issues, which have supported them in reaching the superiority about the cost and arouse the overall operational efficiency of their systems, especially logistics operations Evangelista et al. (2012). [3]

According to shipper's perspective, the Fail Relationship (FR) is formed by a dependency relationship with LSP that caused a large risk, thus the suitable LO relationship management has been stressed about its important roles (Tsai et al., 2012) for enriching the performance of LO control (Chu et al., 2016). In addition, the escape of responsibility, perception of opportunism, business conflicts of interest, lack of expertise and reveal each other's business secrets which cause to the shorter three to five years existence of LO relationships (Sangam, 2015). [4-6].

Therefore, the tightness of the LO relationship should be regularly rated to minimize the risk which can influence to the performance of logistics operations. Kumar and Singh (2012) and Liu et al. (2011) have revealed that two most significant criteria that have rated the service level of LSP, are logistics the cost related to logistics operation and the cost for on-time delivery. In which, the second criteria, Liu et al. (2011) has illustrated the significant results in increasing the cohesion degree when shippers are committed by LSP for the on-time delivery [7-8].

Research on maintaining LO relationships, Jayaram and Tan (2010) have provided various citations and guidelines within the linkage of onshoring and offshoring operations to enhanced performance. However, the authors have not offered any recommendations to solve the performance problems, but only called for more research into LO relationships. The application on SuC management, Lam et al. (2015) and König and Spinler (2016) have concurred that LSP have played key roles in reducing the overall risks in the SuC operation. [9-11]

In this study, the objective to concentrate the LO relationship for orienting the future logistics operation deal with Rice SuC in Mekong Delta, Vietnam, within an LO context which the enterprises in this area are forced the pressures by Vietnam Government for changing to using LO service. The LO relationship framework will be derived from the integrations of an extensive literature review, the Experts ideas and the real information which is arranged a logical 
order to make sure that only the main factors influencing LO relationships will not be missed.

The remaining parts are constructed as follows. The various enablers of LO relationships are discussed in the literature review. Next, the methodology which is built by the integration of FISM-FMICMAC-FAHP will be mentioned in next part. The next part is the illustration of the FISMFMICMAC-FAHP methodology applied to Mekong Delta (Vietnam) Rice SuC context. Finally, it is shown the conclusions and recommendations for future studies.

\section{LITERATURE REVIEW}

\section{A. Top Management Championship (TM)}

$\mathrm{TM}$ involvement is a prerequisite and necessary to enable SuC cooperation (Ireland et al., 2020). On the other hand, compared to the term "Top Leadership Support", the championship embodies a more active role of top management and emphasizes their ability to take the initiative to take the lead in LO (Chatterjee et al., 2002). In addition, the lack of senior management involvement is a multiple barrier to the development of appropriate logistics strategies (Gunasekaran et al., 2003). Often, TM is not aware of the true value of our SuC operations and our probable contributions to long-term competitive advantage (Hammer and Michael, 2004). Besides that, supporting TM as a key element of internal cooperation (Ellinger et al., 2006) and the logistics department may have more powers to cooperate with the 3PL and, if necessary, cooperation can be taken to a more specialized level (Sandberg and Birgitta, 2007). [12]

Moreover, LO relationship variables can be also modeled to improve both the performance and the competitiveness of the store owners in the SuC of logistics (Qureshi et al., 2008). Along with that one needs to be concerned about companies process reengineering as it has become a useful arm for any business model looking to increase its existing organizational productivity and intend to get a cost-leading strategy in its industry, and its operating environment (Magutu et al., 2010). [13-14]

To be more complete, we need to incorporate the concept of work and waste at every step in any process and the goal is to eliminate trash y elements and try to enrich the elements work factor (Ragab, 2009). The support of TM is another important factor which arouses the capability of top managers to offer the orientations, resources, and requirements to be needed during, and after the acquisition of blockchain technologies in LO companies (Queiroz and Wanba, 2019). Yuan et al. (2020) emphasized the critical role of top management in mediating transaction attributes to practice their effectiveness on LO's success. [15-17].

\section{B. Personal Relationship/Guanxi (PR)}

PR represents a company and an important human resource in the business community and problems need to be deployed to enhance a company's competitive advantage (Peng et al., 2000). Although there are similar concepts in other countries as "Pratik" in Haiti, or "chaebol" in South Korea, the PR term is unique to Chinese culture in many ways (Grewal et al., 2002). For foreign companies operating in China or having Chinese firms as partners in their SuC, it is significant to know the implications of developing PR in China (Handfield et al., 2005, Shou et al. 2017). [18]

Furthermore, people in the PR network are committed to the others based on a reciprocity expectation regarding equity and incentives exchange (Leung et al., 2005). In addition, as a network, PR is also seen as an important form of social capital for companies (Szeto et al., 2006; Shou et al. 2017). [18].

Besides, PR has helped the global LSPs to warrant their own market share in the China Market by signing the strategic contracts with domestic LSPs (Liu et al., 2018). Although PR has received considerable attention from researchers in other business areas, empirical research is still lacking in logistics and supply chain management. Guanxi mentions informal individual relationships that make easier the exchange of grace between people. In essence, Quan Tay is a type of PR characterized by friendship, belief, and interdependency $(\mathrm{Gu}$ et al., 2008). On the other hand, the recent research has proved that the interpersonal PR is valued as the social capital to help solving the LSPs' problems and improve LO relationships in China (Chen et al., 2015) and it can also be applied at the constitutive level (Cai et al., 2010). [19-23]

\section{Commitment Trust (CT)}

In an inter-organizational scene, the Trust can be defined as "the belief that one's partner will act in a predictable manner, will keep its word, and will behave in a manner that does not negatively affect to the other" Spekman et al. (2002). Trust is also defined as a partnership-based decision with the prospect that the partner will act following to mutual agreement. Interorganizational trust establishes a situation, where enterprises are driven to overcome the minimum claims of a LO relationship to stimulate the win-win relationship. Moreover, it has been proved that Trust is often low at the onset of a 3PL partnership and is a necessary in the business development strategy (Knemeyer et al., 2003; Klein, 2007). In turn, Trust allows for transparent and effectual communication because the partners will tend to the open mind in sharing their intellectuality and the value information. when they keep in trust to the other ones Ghosh and Fedorowicz (2008). [24-25] Others suggest that contracts are the basis for trust Hofenk et al. (2011), and Gao et al. (2017) found that the similarity of partners and the ability to manage the alliance contribute to the stability of the alliance and the effectiveness of the relationship. Several key research that appeared the sector is a relatively "new" area for management in SuC; lack of agreement on the name of the term. The studies of trust's types which included institutional and rational trust, and decisionmaking over the trust, are often negligible attention Tejpal et al. (2013). [26-28]

Yuan et al. (2018) argued that Commitment (Co) has had the positively affects performance in the $\mathrm{SuC}$ and Yuan et al. (2018) also proved that Co has become the mediated stage in the relationship between the coordination performance and Trust. Individuals who believed each other are ready to reveal their own opinions, to give exchanging information, setting, and clarifying goals, solving problems and being able to work together to improve cooperation effectiveness (Huo et al., 2015) [29-30]. 


\section{Cultural aspects influence the logistics operation (CUL)}

Cultural incompatibility, which is revealed, have often leaded to the failure of a 3PL partnership Wilding and Juriado (2004). Others state that the cultural diversity can significantly influence the way that the managers make final decisions because they are bared great impacts by the CUL where they live Panayides (2007). Some authors emphasized the important role of having the partner's organization CUL. The authors also identified that the consistent interaction which combines to an open exchange of latent disputes, is needed for the partners to understand the CUL each other. The conflicts in CUL can cause to the opposites in controlling the business at some nations. The Saudis, for example, favor individual relationships over assignments, while the Swedes put that in revers Hofstede et al. (2010). To exploit the advantages of positioning abroad effectively, companies must also choose the most suitable management method based on the need to control overseas services, the level of commitment desired depends on effort and investment they are willing to make (both tangible assets and human capital), and the degree of risk associated with an overseas deployment Hutzschenreuter et al. (2011). [31-32]

Furthermore, the cultural gap is defined as a multiple obstacle in out-sourcing relationships that they represent in political systems, religions, business practices, or languages differently. They also claim that cultural diversities may be advantages for such relationships Gooris and Peeters (2014). In addition, the organizational culture that includes the behavioral patterns and practices of everyone in the freight logistics company is an important in choosing to use or not to use the technologies to improve performance Schuetz and Venkatesh (2019). Dai et al. (2018) and Dubey et al. (2019) have mentioned the advantages of Constitutive CUL to the way how the enterprises can react to external pressures, and how to make strategic decisions [33-36].

\section{E. The 3PL Customer Service Expertise (PLC)}

Nowadays, logistics out-sourcing operations usually include complex supply chain procedure and advanced IT customized for critical consumers or key accounts. Therefore, 3PL employees 'understanding of the main client's performance issues and requirements and their relationships with peers' employees are key differentiating resources Ellinger et al. (2008). Besides, Service level (SL) management is related to the necessary to create strong LO relationships between its consumers and LSP. SL control should create a tight link between the customer and LSP (Hsiao et al., 2010). There are two main approaches to measuring service quality. One of these approaches is subjective or internal where companies build specifications to evaluate their services (Thai, 2013; Arvis et al., 2018) [37-40].

\section{F. Logistic Performance (LP)}

Often, the LSP's innovation obligations cannot be appropriately predetermined, as it is not clear what innovation could benefit future customers and what technological advancements. will be available to LSP Bhatnagar and Viswanathan (2000). Some authors prove that the various types of cooperation between partners will produce the perfect interactions, which leads to the improvement of the innovation abilities of channel echelons Stahl et al. (2003) and Roy et al. (2004). Others emphasizes that business can be a market leader only when its logistics operations are accompanied the efficiency in "service lead and cost" Christopher (2005). Besides, innovation mentions to any change in radical or incremental characters, which manifests itself in products and processes and consists of a change in services or governance activities Sher et al. (2005). Innovations can also target multiple customers, including full group or subgroup of customers. These innovations promote LSP's competitive advantages for services provided in upcoming or existing LO relationships in the form of adaptive agreements Williamson (2018) [41]. Fortune 500 companies can be completely known their LP by the comparing results with their competitors Daugherty et al. (2009) [42]. In these studies, the main items on the LP of 3PLs are usually promised delivery times, ontime delivery, logistics costs, flexibility, etc. Marcus et al. (2010) [43]. Additionally, performed a comparative analysis from the two-side point of view by collecting data from both 3PLs and customers (large manufacturing companies), the authors also use the variables of financial performance and efficiency Liu and Lyons (2011), Mothilal et al. (2012) [8, 44], and those directly related to logistics services for improving the benefits such as better service, a higher rate of on-time delivery and accuracy, quick response, more satisfaction with the level of service, more additional services, lower logistics costs Karia and Wong (2013) [45]. Furthermore, Zailani et al. (2017) [46] build the relationship levels between LP and customer satisfaction by the 3PL vendor selection criteria to measure operational performance. In addition, some authors found that reducing logistics costs is the most important factor to improve Vietnam's logistics system, followed by logistics services. They note the importance of the LSP but also argue that Vietnamese logistics companies lack international competitiveness.

\section{G. System compliance (SC)}

The development of LSPs' role has also aroused the need for measuring the LSPs' effectiveness that directly impacts the performance of the entire SuC Van-Hoek (2000). Some authors believe that the IT integration (ITI) projects will be matched the technical requirements more exactly when the regular and advanced communication was conducted on the right way and controlled tightly Nah et al. (2003), they also suggest that companies' IT capabilities can improve organizational learning, contributing to corporate performance Tippins and Sohi (2003). In addition, within the $\mathrm{SuC}$ network, LSP work as the bridges to link processes in the upper and lower SuCs Chan and Chung (2005), and they foster an IT system in a way that assists shippers in evaluating the cost 3PLs' efficiency Halldórsson and Skjøtt-Larsen (2004). Overall, IT has been widely recognized as an important factor in the $\mathrm{SuC}$, which helps to increase the effectiveness of not only the firms but also the entire SuC. However, Sanders et al. (2007) found the presence of the inconsistent results when the research that analyzed the direct influence of IT on specific performance measures, were conducted [47]. They argue that the higher the ITI between all SuC's sides which can leading to increased transparency in operations, thus fostering trust 
(Sinkovics et al., 2011) [48], and emphasizing the progressive link between data collection technology with efficiency and performance [3]. On the other hand, digitization is a new relational model across the entire SuC network (Yuan et al., 2020) [22]. Digitization helps the business to be supported better than ever before when the manual performances will be substituted by the electronic communication and communications technology systems (Chang et al., 2019) [49].

\section{H. Standardization (ST)}

They state that the standardization of Logistics Procedures (LoPr) leads to improved competitiveness in operations. They also emphasize that implementing process standardization comes with geographic and cultural challenges that need to be considered when doing business across borders Manrodt and Vitasek (2004). Others state that LoPr need to be standardized in accordance with general international standards and practices, for example, including logistics facility-specific or normal measures equipment. Besides, they also clarify that the standardization of logistics is conducted completely only when the packaging, the barcode logistics, and consolidation of containers for handling, transport, and storage are implemented synchronously. In addition, this standardization is becoming an effective way which helps to minimize the logistics costs and improve overall operational efficiency (Zhao and Tang, 2009) [50]. Some authors agree that 3PLs adopt shipper standards to ensure improved productivity (Large et al., 2011) [51]. Specifically, it is explained that efficiency-focused 3PLs has tended to provide standardized solutions which achieved a yield rate as high as to how to exploit economies of scope and scale and achieved a deeper "customer adaptation", requiring the higher capacity from each shipper (Marchet et al., 2016) [52].

\section{Contract length $(C L)$}

The long-term agreement must be in accordance with changing market conditions, public technology, and customer needs (Webb and Laborde, 2005). Our evidence links the performance of on-time delivery with the degree of contractual clarity; without a clear service definition in the contract, it will take longer to clarify the scope of each delivery which caused to delayed or missed deliveries. Indeed, contracts must be based on transparency and clarity Halldórsson and Skjøtt-Larsen, 2004). Such a conception could support another author's argument (Rajesh et al., 2011) [53], by proposing to carefully consider the 3PL's amplitude of freedom when establishing agreements. Furthermore, smart contracts can control digital operations effectively, thereby increasing outsource costs, simplifying the management process and risk mitigation (Helo and Hao, 2019) [54]. Therefore, this has ensured that the information and currency flows can be fast smooth without using the intermediaries, namely as custom clearing companies and banks Chang et al. (2019) [49].

\section{J. Coordination/ Buyer-3PL Collaboration (COL)}

In the present studies, the cooperation between LSP and Supplier is considered as a kind of capacity to support Supplier in developing decision ownership and responsibility with its main LSP. Specifically, Collaboration involves good relationships that emphasize information sharing and coordinate processes to jointly explore market opportunities and generate new ideas. The 3PL provides resources and assets that the acquirer may not have (Robert and Kendrick, 2003). Compared to companies that view outsourcing logistics as a commodity, companies that have a close working with their 3PLs are more likely to respond to changing market needs and needs. and customers. Consequently, the 3PL-buyer partnership demonstrates the unique ability that an owned (Rudolf and Anthony, 2004). Working with a large 3PL vendor encourages a company to integrate an integrated purchase of the organization's processes and activities, thereby enhancing corporate alignment and use of company resources. Furthermore, the company's capability to connect with key 3PL vendors also facilitates the growth of other key abilities such as responsiveness, flexibility, and learning abilities Esper et al. (2007) [55]. Finally, they also consider about collaboration a documentary concept of Cooperation (Coop.) refers to it as an organization of activities under the existence of Coop. Coop is then understood as the result of the connection between the two exchange parties. In addition, the activities in same environment are not necessarily reflect cooperation, as they can simply be imposed on partners through the exercise of power (Obadia, 2008). The state of the buyer-supplier relationship may also influence on performance metrics (Hald and Mouritsen, 2018) [56] and the relationship degree. DUC et al. (2018) [57] have mentioned the important role of logistics and the LO relationships in building a mathematical model revolving around partners in the $\mathrm{SuC}$ to maximize $\mathrm{SuC}$ operations.

\section{$K$. Productivity enhancement and competitive advantage} $(P E)$

Well, the top level of excellence is required for a variety of clients, to respond to their strategic target in the properties of the product. The logistics needs to hire out the underlying basis of the people who need to send their product, in most the cases, they've created specialists to serve better relatives, the software needs to provide access to a group of people with lower costs (Langley, 2000). It improves the focus in a dark direction that maximizes value to increase productive, energy and increased value. It also provides the edge of competition by providing more quickly and allows you to approach and evaluate the technology, new market (Sloper, 2004). Besides, the benefits of upcoming hosts allow the hosts to gain more parts, the idea that the relationship will be the source of the future, and the commitment or the trust is necessary for this relationship (Yilmaz et al., 2005) [58]. They also found out about flexibility, which is the most important ability to resist the uncertainty of the environment Eric et al. (2006) [59]. Competitive pressure is a significant factor which caused the constant urge between logistics companies in proving their competency with partners or investors (Angelis, 2019)) [60]. Competition pressure and globalization have motivated LSP to find ways how to develop and enhance their own competitive advantages (Nguyen, 2013) [61]. In addition, it is difficult that the new technologies can be applied the logistics industry unless there are the government assistance and enact rules and regulation, for example, the blockchain technology 
(Montecchi et al., 2019) [62].

\section{Evaluation of supplier performance (ESP)}

It is realized that collaboration is actively impaired whether the high-end trading environment or low, all this reasoning shows that cooperation can protect international exchange and create an environment where there's a trade level of communication and sharing knowledge higher (Cannon et al., 2000). They also emphasize the high value of the provider's achievement to promote their good relationship to the highest bidder for the upgraded in the entire organization, committed to an inability, so provide more improvements or allow the partners to continue to exist in many more crisis (Bullington, 2005). There is a clear agreement that the administrator based on standard has a positive effect on the company (Kim et al., 2006) [63]. According to the RBV, the autonomy agencies, as the belief is the main motivation of the business competition, especially in the national exchange, where the separation between the partners made the traditional contract deal become attractive. Some of the research provides evidence that the standard of the role-playing system as a productive administrator helps the advantage of the company and limit the opportunity of the business on the international business market (Wu et al., 2007 [64]. The importance of measuring the loss of the supply chain is growing along with the importance of the suppliers to the success of the companies. However, the administrator of the suppliers and the supply chain are a challenge to the complex companies of social ties and connections (Maestrini et al., 2007). The strategic relationship between the buyer and the supplier is drawing attention increasingly increasing in the documents (Agarwal et al., 2010; Krishnan et al., 2016) [65, 66]. This kind of relationship is getting more important in management of transactions. Using information about efficiency and results can be different between strategic suppliers and strategic factories and no strategic strategies Hald and Mouritsen, 2018) [67].

\section{Added distinctive value through (total quality management) TQM and (just in time) JIT practice $(A D V)$}

Dell's computer has used the advantage of hiring out and contract contracts with third suppliers to rent out most of his client services while the company is focusing on the right warehouse patterns and distribution system with the online distribution system. The last thing is to maintain the competition's profits and notice that the competition is difficult to replicate the procedure like that or even replace a new change like that (Ranjith and Bijuna, 2013) [68]. Tasie (2016) [69] recommends that the unique features of TQM are to use the science approach in making decisions and solving problems, attachment and privileges to the staff, improve the endurance of the process, focus of the client and outside. According to Flynn (1995) [70], the concurrence between JIT and TQM can improve efficiency. Furthermore, Green et al. (2019) [71] suggests that the "three-zero production model", which requires production managers to simultaneously achieve defect-free, waste-free and zero-emissions to the environment and no inventory suggesting that it can is done through JIT, TQM and GSCP.

\section{N. Dedicated Resources (DR)}

According to Rutner and Langley (2000), logistics efficiency is required to meet their objective of product delivery optimization. LO helps to solve the shippers' limitations in investing on the logistics infrastructure requirement while these shippers can take care their customers as well as possible. LO can completely generate DR to serve their shippers in a better way. LSP access to dedicated RESOURCES of the experts at lower costs, whose skills can promote the existing technologies, especially Information Technology (IT). IT has caused a logistics revolution, which helps to increase the efficiency and the ability to meet demand Gunasekaran et al., 2017) [72]. The companies which have properly invested IT/ICT resource, will create the positively influence to quality, production efficiency and the added value in the logistics and SuC management (Brinch et al.,2018) [73]. In addition, Belvedere et al. (2017) [74] proved that the effectiveness from IT in the current digital transformation revolution can motivate all logistics activities. These activities often consist of transportations, storages, and warehouse control. The popularity of E-commerce has forced the LSP concentrating more on the key factors of the LO relationship (Evangelista et al., 2012) [3].

This study attempts to provide the logistics managers a detailed outline for potential supporters and impediments impacting their LO relationship, and consequently enhance the LP outcome.

The main contributions are included the contents as follows:

The relationship in Logistics Outsourcing (LO) activities currently has not received much attention from businesses in Vietnam. Logistics studies in Vietnam have so far not focused on studying the factors affecting the relationship of outsourced logistics. In this paper, we delve deeper into this problem of outsourced logistics relationships. In addition, the factors that we studied were gathered and considered in the same context from many research studies that have been carried out up to the present time and the contributions of leading logistics experts in Vietnam. In Vietnam, the problem has not appeared in articles written on logistics, and especially articles written on logistics activities in Vietnam, for the rice supply chain in the Mekong Delta.

In addition, the mutual impact of supporting factors in the LO relationship between shippers and LSPs has been modeled under a new approach, which has not been found in LO studies, especially than studies related to LO in Vietnam's rice supply chain. The approach considered is the integration between FISM, FMICMAC and FAHP under Trapezoidal fuzzy numbers. The FISM-FMICMAC-FAHP integration method was not found in the studies on the LO relationship of the Vietnamese rice supply chain while the trapezoidal fuzzy language was integrated into the research method development process as well. This is the main contribution of this paper. The factors supporting the LO relationship were modeled based on their driving power and dependence. Since, the research objectives are addressed:

1. To develop FISM-FMICMAC analysis in clustering 14 enablers which are drawn by the literature and the discussion with practitioners and academicians.

2. To integrate FAHP to formulate FISM-FMICMACFAHP methodology to determine the global weights 
in the relationship between the clusters and enablers in the clusters identified from the FISM - FMICMAC classification.

3. To identify the best driving enablers which significantly influenced LO relationship.

Finally, the factors affecting the LO relationship have never appeared in studies on rice supply chains in the Mekong Delta, Vietnam. Therefore, the conclusion of the thesis will be an important input to help business managers, especially enterprises related to the rice supply chain, understand the crux of the LO relationship. From there, they can make more appropriate decisions to improve LO performance and help businesses survive and develop. This is also a contribution of this article to business management.

\section{MethodOLOGY}

This paper develops a new approach which consists of both the integration and analysis to model and rank the enablers of loyalty in LO relationship in out using a integrated FISMFMIMAC-FAHP approach. In this approach, the literature, real Logistics operation and experts' ideas are combined to derive 14 independent variables which are represented by 14 the impact factors to the LO relationships. These variables will be analyzed to determine the specific importance and relationship through the ISM method considered under fuzzy values. The results by FISM will be categorized into four clusters under FMIMAC method. In this stage, the variables belonging Independent and linkage clusters are considered for the AHP method. Then, AHP is used to determine the Final ranking of the relative weights under fuzzy value. All the fuzzy value sets which are calculated in this paper, are the Trapezoidal Fuzzy (TF) Savitha and George (2017) [75]. The research's framework has been shown in Figure 1.

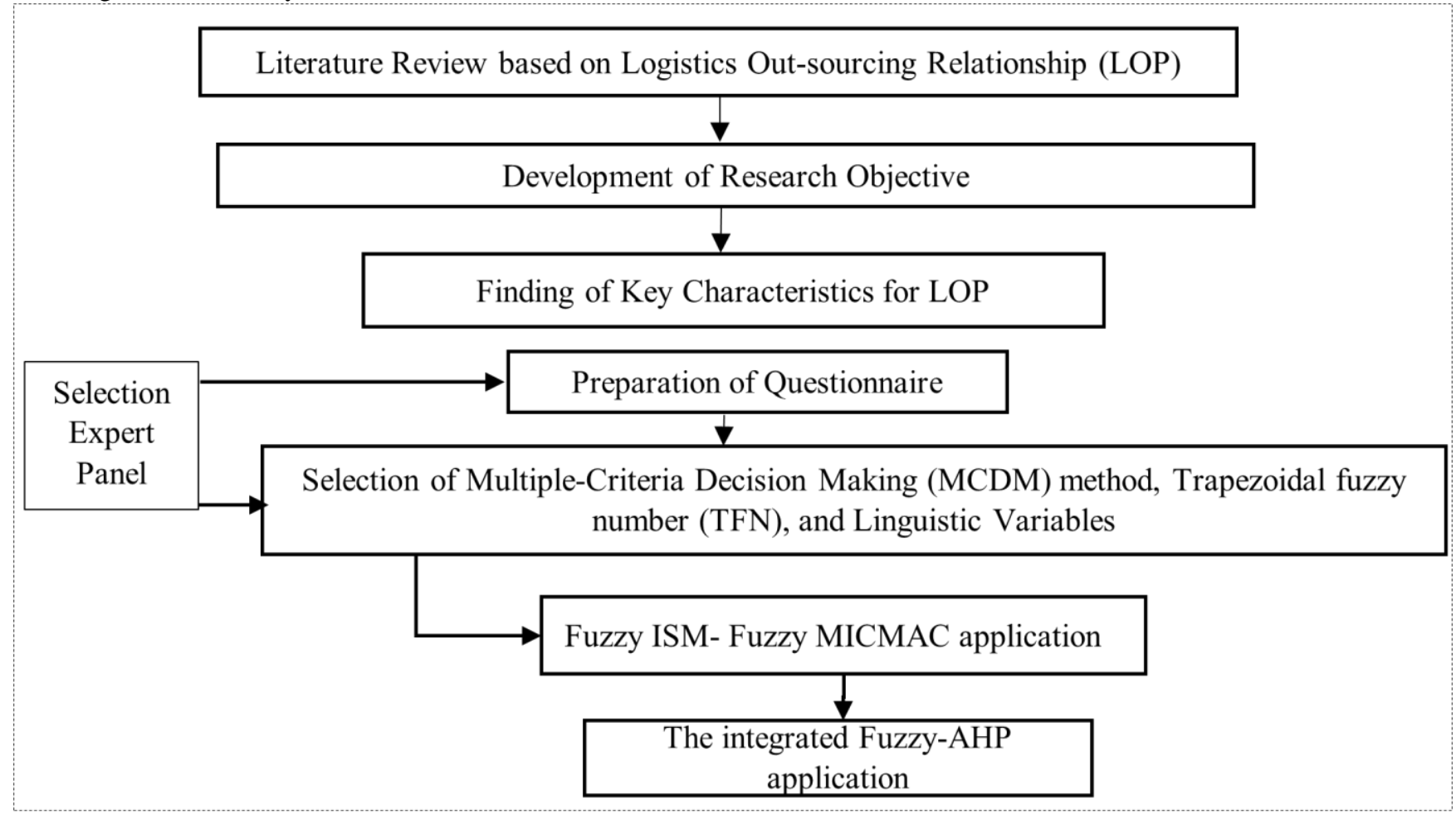

Figure 1. The Study framework

According to Figure 1, data collection will be developed from both primary and secondary sources. Secondary sources are information provided from leaders of Shippers and LSP and Experts, Published reports, articles and internet. Meanwhile, primary resources are made available to employees of relevant units through questionnaire surveys, telephone interviews and personal visits.

Characteristics of LO were implemented after review of the document and discussion with Experts. In this study, the literature from 2000 to 2020 was reviewed. Furthermore, there are very few published results which are closed related to the concept of LO Relationships. A rigorous search was performed using groups of keywords that were characteristic and fully reflective of the LO Relationships-related aspect to collect research papers for review. This rigorous search 's results then have been discussed by a council of 10 experts/researchers under the Delphi technique to find out the 14 main drivers from sustainably LO Relationships in the Mekong Delta, Vietnam. Key components of the Delphi technique include the communication process, an essential group of experts and feedback Yousuf (2007), Dube and Gawande (2016a)[76].

These 14 factors will be incorporated into the survey to prepare for the primary data collection process under the requirements of ISM Method. The data survey subjects are concentrated of 10 experts/researchers and 130 enterprises (13 provinces/city in Mekong Delta, respectively), who have managed/operated logistics' solutions, who have been approached the LO services for over two years.

FISM method in this research is an extended fuzzy format of ISM Savitha and George (2017), Yadav and Sharma (2017), Lamba and Singh (2018), Rana et al. (2019), Mishra 
et al. (2019), Rajput and Singh (2019) [75, 77, 78, 79, 80, 81]. In this article, the FISM is used in the integration with FMICMAC to form a consolidation method or FISMFMICMAC method. The steps of the proposed methodology is described as follows Yadav and Singh (2020) [82]:

- FISM application

+ Aggregated Structure Self- Interaction Matrix (ASSIM)

+ Initial Fuzzy-Reachability Matrix (IFRM) under Linguistic Variables (LVs)

+ Develop the Binary Relationship Matrix (BRM)

+ Show transitive links in Final Defuzzified Reachability Matrix (FDRM).

+ FISM Hierarchy model

- FMICMAC

+ IFRM under Fuzzy number.

+ Final Average Crisp Values (CV) of dependence and driving power.

+ Classify Characteristics into four zone

+ Finding of Common Driver Characteristics

As mentioned before, the FAHP methods will be concentrated on the factors beloging the independent and linkage clusters which have been resulted by FISMFMICMAC approach. FAHP method is an expanded form AHP, which is a popular method to solve complex Multi Criteria Decision Making (MCDM) problems quickly. MCDM problems have been involved many types of conditions in which qualitative and quantitative issues are the most popular Saaty (1980), Saaty and Thomas (2000) [83]. In FAHP method, a complex MCDM problem will be broken down into a hierarchy of decision elements (see Figure 2).
However, the weak point of FAHP is that the experts have important roles in building the evaluation matrices, pairwise comparisons. Moreover, the consistency ratio (CR) must be calculated to check the consistency of evaluations. If the CR value exceeds 0.10 , the process will be returned to the step of pairwise comparisons Alptekin, and Büyüközkan (2007), Rajak et al. (2016) [84].

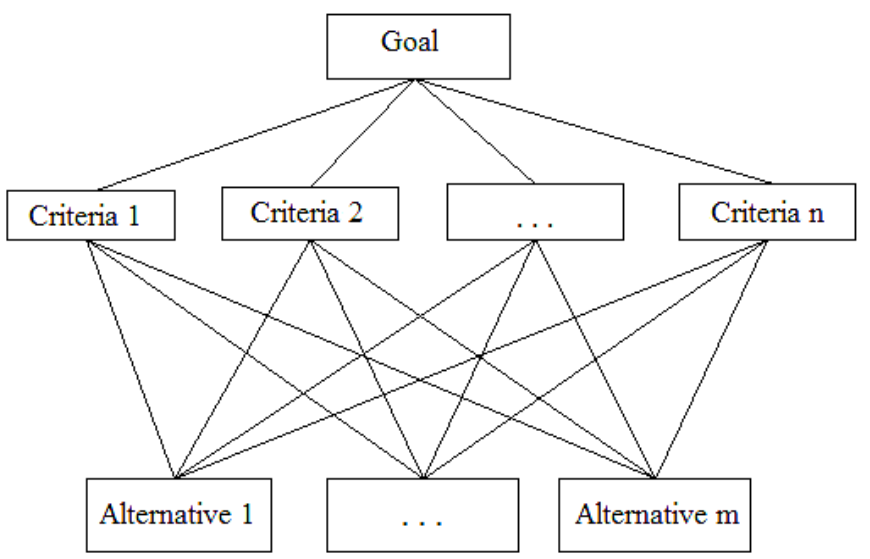

Figure 2 The general structure of AHP (Saaty and Thomas, 2000) [83]

In this article, FAHP method is structured by adjusting from the basic AHP method which help clarifying the importance of factors affecting LO relationship by numerical values in fuzzy set format. Accordingly, a FAHP diagram integrated with the results of the FISSM-FMICMAC approach that has been developed based on the improvement from Do et al. (2015) [85], which is shown in Figure 3.

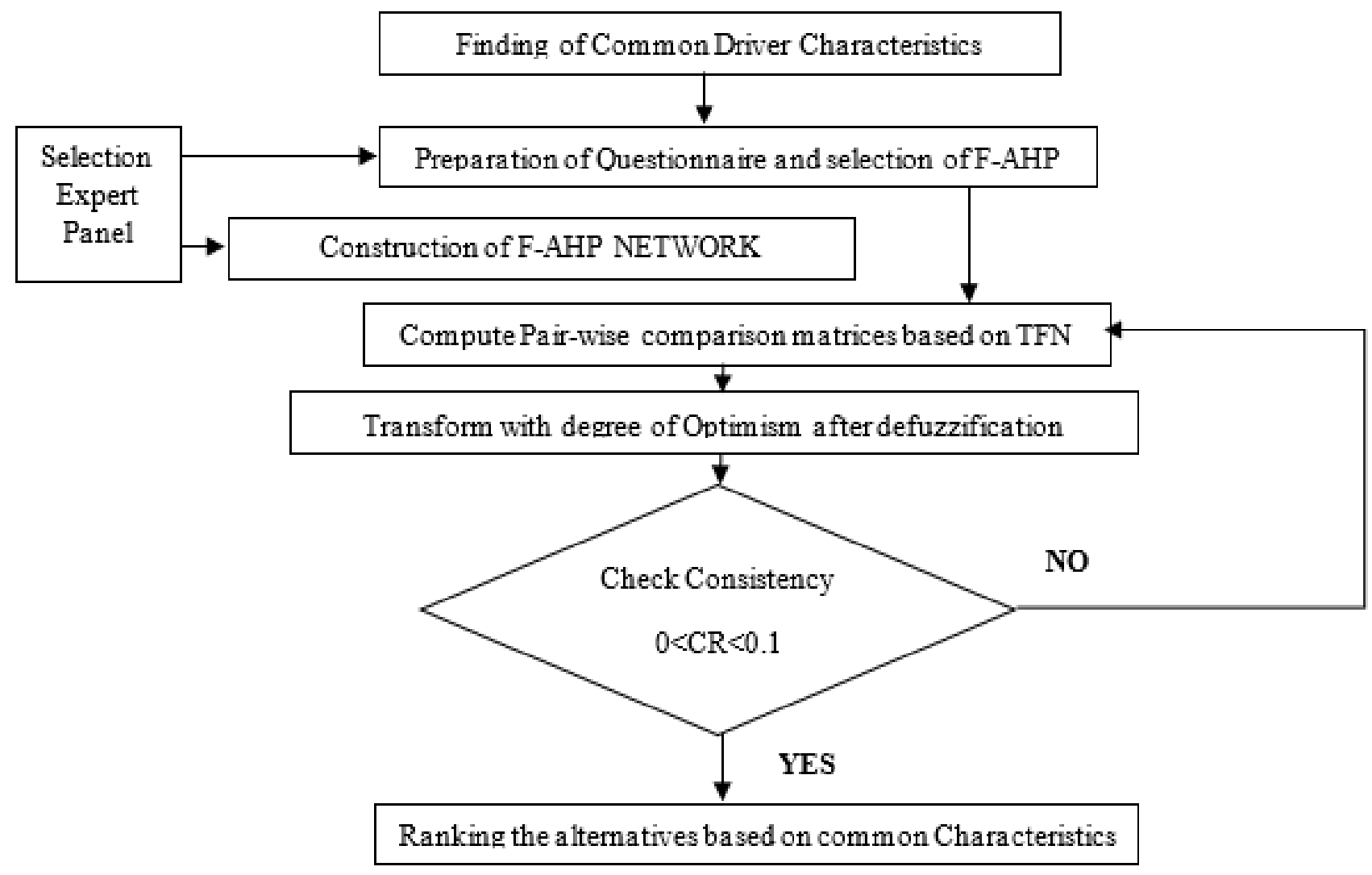

Figure 3 The flow chart of the integrated FAHP method 
However, the fuzzy set in FAHP is not same with Fuzzy set in FISM-FMICMAC even though the trapezoidal rule is still used, respectively. The theory of first fuzzy set was has created by Zadeh (1965) to solve the uncertainly problems which are caused by imprecision or vagueness. A fuzzy set $A$ in a universe of discourse $X$ is defined as the set of pairs, $A=$ $\left\{\left(x, \mu_{A}(x)\right): x \in X\right\}$, where $\mu_{A}(x): X \rightarrow[0,1]$ is called the membership value of $x \in X$ in the fuzzy set $A$ [86].

According to Sanhita and Tapan (2012) [86], A Trapezoidal fuzzy number (TFN) denoted by $A$ is defined as $(l, m, n, u)$ where the membership function is given by function (1).

$$
\mu_{A}(x)=\left\{\begin{array}{rl}
0, & x \leq l \\
\frac{x-l}{m-l}, & l \leq x \leq m \\
1, & m \leq x \leq n \\
\frac{u-x}{u-n}, & n \leq x \leq u \\
0, & x \geq u
\end{array} .\right.
$$

A Fuzzy Number (AFN) $A$ is a fuzzy subset of the real line; $A: R \rightarrow[0,1]$ satisfying the following properties Ban and Coroianu (2015) [87]:

(i) $A$ is normal (i.e. there exists $x_{0} \in R$ such that $\left.A\left(x_{0}\right)=1\right)$

(ii) $A$ is fuzzy convex;

(iii) $A$ is upper semi continuous on $R$. ie; $\forall \varepsilon>0, \exists \delta>0$ such that $A(x)-A\left(x_{0}\right)<\varepsilon$ whenever $\left|x-x_{0}\right|<\delta$;

(iv) The closure, $\operatorname{cl}(\operatorname{supp}(A))$ is compact.

The $\alpha$-cut, $\alpha \in(0,1]$ of AFN $A$ is a crisp set defined as $A(\alpha)=\{x \in R: A(x) \geq \alpha\}$. Every $A_{\alpha}$ is a closed interval of the form $[A L(\alpha), A U(\alpha)]$.

The AFN's value $A$ is denoted by function (2).

$\operatorname{val}(A)=\int_{0}^{1} \alpha\left(A_{u}(\alpha)+A_{L}(\alpha)\right) d \alpha$

According to [112], it is assumed that TFNs: $A_{1}=\left(a_{1}, a_{2}\right.$, $\left.a_{3}, a_{4}\right), A_{2}=\left(b_{1}, b_{2}, b_{3}, b_{4}\right), \ldots, \mathrm{A}_{n}=\left(n_{1}, n_{2}, n_{3}, n_{4}\right)$.

$A_{v}=\frac{\mathrm{A} 1+\mathrm{A} 2+\cdots+A_{n}}{n}=$

$\left(\frac{a_{1}+b_{1} \ldots+n_{1}}{n}, \frac{a_{2}+b_{2} \ldots+n_{2}}{n}, \frac{a_{3}+b_{3} \ldots+n_{3}}{n}, \frac{a_{4}+b_{4} \ldots+n_{4}}{n}\right)$.

Then the membership function of the arithmetic mean $A_{v}$ is given by (4):

$$
\mu_{A_{V}}(X)=\left\{\begin{array}{cc}
\frac{X-M A}{M B-M A} & \text { if } M A \leq X \leq M B \\
1 & \text { if } M B \leq X \leq M C \\
\frac{M D-X}{M D-M C} & \text { if } M C \leq X \leq M D \\
0 & \text { otherwise }
\end{array}\right.
$$

where:

$$
\begin{aligned}
M A & =\frac{a_{1}+b_{1} \ldots+n_{1}}{n} . \\
M B & =\frac{a_{2}+b_{2} \ldots+n_{2}}{n} . \\
M C & =\frac{a_{3}+b_{3} \ldots+n_{3}}{n}, \\
M D & =\frac{a_{4}+b_{4} \ldots+n_{4}}{n} .
\end{aligned}
$$

There are various types and procedure of FAHP Bozbura et al.(2007), Elif et al. (2016) [88]. In this study, we try to enlarge the FAHP approach of Savitha and George (2017) [75] to implicate improving the LO Relationships.

\section{DISCUSSIONS AND RESULTS}

\section{A. Using FISM-FMICMAC to cluster Enablers}

To establish a SSIM, data from a council of 10 experts/researchers and 130 enterprises (13 provinces/city in Mekong Delta, respectively), who have managed/operated logistics' solutions, are collected. These have been approached the LO services for over two years. The LO relationships are belonging to the nature of their partnership which determined the loyalty factors between the respective partners. The SSIM in this study is combined with the Fuzzy Linguistic Scale (FLS) to create the ASSIM.

In this study, 14 enablers which are mentioned, consisting of Top Management Support (TM); Guanxi/Personal Relationships (PR); Commitment or trust (CT); Culture (CUL); 3PL Customer Service Expertise (PLC); Logistics Performance (LP); System Compliance (SC); Standardization (ST); Contract Length (CL); Buyer-3PL Collaboration (COL); Productivity Enhancement and Competitive Advantage (PE); Evaluation of supplier performance (ESP); TQM and JIT supplier added (ADV) and Dedicated Resources (DR). Béides, the two trapezoidal fuzzy sets will be used for all fuzzy approaches in our methodology. The First set is

\begin{tabular}{|c|c|c|c|}
\hline Linguistic description & Notation & TFN & $\begin{array}{c}\text { Influenc } \\
\text { e scope }\end{array}$ \\
\hline $\begin{array}{l}\text { Extremely } \\
\text { insignificant }\end{array}$ & $\mathrm{NO}$ & $\begin{array}{l}(0.00,0.05, \\
0.15,0.25)\end{array}$ & 0 \\
\hline Insignificant & VL & $\begin{array}{l}(0.15,0.25, \\
0.35,0.45)\end{array}$ & 1 \\
\hline Equally significant & $\mathrm{L}$ & $\begin{array}{l}(0.35,0.45, \\
0.55,0.65)\end{array}$ & 2 \\
\hline Moderately significant & $\mathrm{H}$ & $\begin{array}{l}(0.55,0.65, \\
0.75,0.85)\end{array}$ & 3 \\
\hline Extremely significant & $\mathrm{VH}$ & $\begin{array}{l}(0.75,0.85, \\
0.95,1.00)\end{array}$ & 4 \\
\hline
\end{tabular}
applied to FISM-FMICMAC stage while the rest one represents in FAHP. Defuzzification and implementation method is adopted by Savitha and George (2017); Lamba and Singh $(2018)[75,78]$ from the fuzzy numbers in Table 1.

Table 1. Fuzzy linguistic scale

\section{Source: Lamba and Singh (2018) [78]}

According to Table 1, moderately significant for the element $(\mathrm{i}, \mathrm{j})^{\text {th }}$ is represented by "VH", which is represented by the TFN $(0.75,0.85,0.95,1.00)$ and vice-versa, for the $(\mathrm{j}, \mathrm{i})^{\text {th }}$ element, the TFN is $(0,0.05,0.15,0.25)$. The relative level of both $(\mathrm{i}, \mathrm{j})^{\text {th }}$ and $(\mathrm{j}, \mathrm{i})^{\text {th }}$ elements and vice-versa are explained by detail in Table 2.

Table 2. Fuzzy trapezoidal linguistic values

\begin{tabular}{lcl}
\hline Notations & \multicolumn{1}{c}{$\mathbf{i}, \mathbf{j}$} & \multicolumn{1}{c}{$\mathbf{j}, \mathbf{i}$} \\
\hline V(VH) & $0.75,0.85,0.95,1.00$ & $0.00,0.05,0.15,0.25$ \\
V(H) & $0.55,0.65,0.75,0.85$ & $0.00,0.05,0.15$, \\
& & 0.25 \\
V(L) & $0.35,0.45,0.55,0.65$ & $0.00,0.05,0.15$, \\
& & 0.25 \\
V(VL) & $0.15,0.25,0.35,0.45$ & $0.00,0.05,0.15$, \\
& & 0.25 \\
\hline
\end{tabular}




\begin{tabular}{|c|c|c|}
\hline $\mathrm{A}(\mathrm{VH})$ & $\begin{array}{l}0.00,0.05,0.15 \\
0.25)\end{array}$ & $\begin{array}{l}0.75,0.85,0.95, \\
1.00\end{array}$ \\
\hline $\mathrm{A}(\mathrm{H})$ & $\begin{array}{l}0.00,0.05,0.15 \\
0.25)\end{array}$ & $\begin{array}{l}0.55,0.65,0.75, \\
0.85\end{array}$ \\
\hline $\mathrm{A}(\mathrm{L})$ & $\begin{array}{l}0.00,0.05,0.15 \\
0.25)\end{array}$ & $\begin{array}{l}0.35,0.45,0.55, \\
0.65\end{array}$ \\
\hline $\mathrm{A}(\mathrm{VL})$ & $\begin{array}{l}0.00,0.05,0.15 \\
0.25)\end{array}$ & $\begin{array}{l}0.15,0.25,0.35, \\
0.45\end{array}$ \\
\hline $\mathrm{X}(\mathrm{VH})$ & $0.75,0.85,0.95,1.00$ & $\begin{array}{l}0.75,0.85,0.95, \\
1.00\end{array}$ \\
\hline $\mathrm{X}(\mathrm{H})$ & $0.55,0.65,0.75,0.85$ & $\begin{array}{l}0.55,0.65,0.75, \\
0.85\end{array}$ \\
\hline $\mathrm{X}(\mathrm{L})$ & $0.35,0.45,0.55,0.65$ & $\begin{array}{l}0.35,0.45,0.55, \\
0.65\end{array}$ \\
\hline $\mathrm{X}(\mathrm{VL})$ & $0.15,0.25,0.35,0.45$ & $\begin{array}{l}0.15,0.25,0.35, \\
0.45\end{array}$ \\
\hline $\mathrm{X}(\mathrm{VH}, \mathrm{H})$ & $0.75,0.85,0.95,1.00$ & $\begin{array}{l}0.55,0.65,0.75, \\
0.85\end{array}$ \\
\hline $\mathrm{X}(\mathrm{VH}, \mathrm{L})$ & $0.75,0.85,0.95,1.00$ & $\begin{array}{l}0.35,0.45,0.55, \\
0.65\end{array}$ \\
\hline $\mathrm{X}(\mathrm{VH}, \mathrm{VL})$ & $0.75,0.85,0.95,1.00$ & $\begin{array}{l}0.15,0.25,0.35 \\
0.45\end{array}$ \\
\hline $\mathrm{X}(\mathrm{H}, \mathrm{VH})$ & $0.55,0.65,0.75,0.85$ & $\begin{array}{l}0.75,0.85,0.95 \\
1.00\end{array}$ \\
\hline $\mathrm{X}(\mathrm{H}, \mathrm{L})$ & $0.55,0.65,0.75,0.85$ & $\begin{array}{l}0.35,0.45,0.55, \\
0.65\end{array}$ \\
\hline $\mathrm{X}(\mathrm{H}, \mathrm{VL})$ & $0.55,0.65,0.75,0.85$ & $\begin{array}{l}0.15,0.25,0.35 \\
0.45\end{array}$ \\
\hline $\mathrm{X}(\mathrm{L}, \mathrm{VH})$ & $0.35,0.45,0.55,0.65$ & $\begin{array}{l}0.75,0.85,0.95, \\
1.00\end{array}$ \\
\hline $\mathrm{X}(\mathrm{L}, \mathrm{H})$ & $0.35,0.45,0.55,0.65$ & $\begin{array}{l}0.55,0.65,0.75 \\
0.85\end{array}$ \\
\hline $\mathrm{X}(\mathrm{L}, \mathrm{VL})$ & $0.35,0.45,0.55,0.65$ & $\begin{array}{l}0.15,0.25,0.35 \\
0.45\end{array}$ \\
\hline $\mathrm{X}(\mathrm{VL}, \mathrm{VH})$ & $0.15,0.25,0.35,0.45$ & $\begin{array}{l}0.75,0.85,0.95, \\
1.00\end{array}$ \\
\hline $\mathrm{X}(\mathrm{VL}, \mathrm{H})$ & $0.15,0.25,0.35,0.45$ & $\begin{array}{l}0.55,0.65,0.75, \\
0.85\end{array}$ \\
\hline $\mathrm{X}(\mathrm{VL}, \mathrm{L})$ & $0.15,0.25,0.35,0.45$ & $\begin{array}{l}0.35,0.45,0.55 \\
0.65\end{array}$ \\
\hline $\mathrm{O}(\mathrm{No})$ & $0.00,0.05,0.15,0.25$ & $\begin{array}{l}0.00,0.05,0.15, \\
0.25\end{array}$ \\
\hline
\end{tabular}

\section{Source: Savitha and George (2017) [75]}

Following FISM process, The ASSIM is established in this study will help to clarify the degrees of pair-wise comparison by FLS. The specific descriptions will be contented in Table 3. From ASSIM's results, the IFRM is made shorter after the comparison the results in Table 1 to Table 3. For example, notation $\mathrm{H}$ in Table 1 is considered as $\mathrm{V}(\mathrm{H}), \mathrm{X}(\mathrm{H})$; $\mathrm{X}(\mathrm{H}, \mathrm{VH})$; $\mathrm{X}(\mathrm{H}, \mathrm{L})$; and $\mathrm{X}(\mathrm{H}, \mathrm{VL})$ in Table 2 for the $(\mathrm{j}, \mathrm{i})^{\text {th }}$ element. After replacing all notations in Table 3 , the new table results have been formed with all notations which are matched with Table 1 , ordered by Table 4 . Table 4 is also named by The IFRM using LVs. Then, these LVs have been converted according to specific rules which are depicted by Table 1 to produce the Initial Fuzzy-Aggregated Reachability Matrix (IFARM) which is depicted in Table 5.
On the other hand, the LVs of Table 4's results $\mathrm{L}, \mathrm{H}$ and $\mathrm{VH}$ are represented by 1 while the value of 0 will be all remaining notations, namely $\mathrm{A}, \mathrm{VL}$, and NO (Luo et al., 2018). According to Luo et al. (2018), the transitivity relationships are parallelly checked from Table 4 to build the FDRM (see Table 6) that is used for calculating the level partitions (LPs). Then, the hierarchy model digraph of FISM is formed from these identified LPs (see Figure 4). LP is established by using the Reachability (Re) and Antecedent (Ante) sets, which are other names of Driving (Dr) and dependent (De) enablers, respectively. The Intersection (Inte) sets is the sets containing all factors of Re set that also belong to Ante set. The enabler which contented common factors in both the reachability and the intersection sets, are leveled as I. The process has been terminated when all enablers are leveled. In this study, the last level is Level VI. Iterations for each enabler is based on Warfield (1974) and are depicted in Table 7. [89]

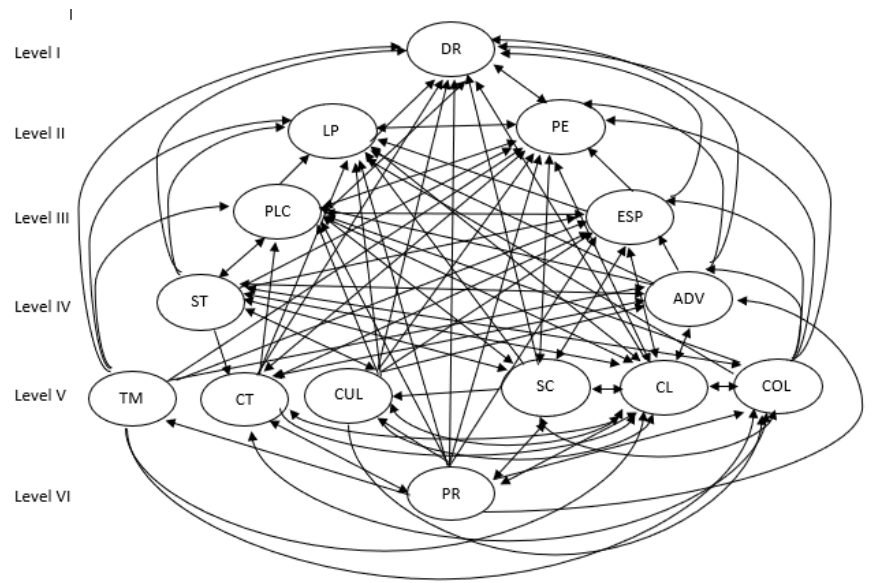

Figure 4. FISM hierarchy model

According to Figure 4, the relationships between enablers under FISM method were specified. These relationships have been further reinforced when it is used integrating with FMICMAC method to become FISM-FMICMAC methodology. In this methodology, Table 5's results have converted into $\mathrm{CV}$ by using function (5). The way how to determine CV in this study, was alluded by [25]. Specifically, $\mathrm{CV}$ for the $\mathrm{i}^{\text {th }}$ and the $\mathrm{j}^{\text {th }}$ enablers is computed by using the following function:

$$
a_{i j}=\frac{2 l_{i j}+7 m_{i j}+7 n_{i j}+2 u_{i j}}{18} .
$$

where $a_{i j}$ is the defuzzified CV and a TFN denoted as $\widetilde{a_{\imath j}}=$ $\left(l_{i j}, m_{i j}, n_{i j}, u_{i j}\right)$.

$\mathrm{CVs}$ of Dr and De powers are computed for each enabler, which caused to the input data for FMICMAC analysis Khatwani et al. (2015) [90].

Using the CVs of Dr and De powers of all enablers from Table 8, FMICMAC's result is graphed in Figure 5. Figure 5 divided itself into four regions, which are as follows: autonomous, dependent, linkage and independent regions. 
Table 3. Aggregated SSIM

\begin{tabular}{|c|c|c|c|c|c|c|c|c|c|c|c|c|c|c|}
\hline & $T M$ & $P R$ & $C T$ & $\begin{array}{l}C U \\
L\end{array}$ & $P L C$ & $L P$ & $S C$ & $S T$ & $C L$ & COL & $P E$ & $E S P$ & $A D V$ & $D R$ \\
\hline$T M$ & 1 & $\mathrm{~A}(\mathrm{~L})$ & $\mathrm{V}(\mathrm{H})$ & $\mathrm{O}$ & $\mathrm{V}(\mathrm{H})$ & $\mathrm{V}(\mathrm{H})$ & $\mathrm{O}$ & $\mathrm{O}$ & $\mathrm{V}(\mathrm{H})$ & $\mathrm{V}(\mathrm{H})$ & $\mathrm{V}(\mathrm{H})$ & $\mathrm{V}(\mathrm{H})$ & $\mathrm{V}(\mathrm{L})$ & $\mathrm{V}(\mathrm{H})$ \\
\hline$P R$ & $\begin{array}{l}\text { V( } \\
\mathrm{L})\end{array}$ & 1 & $\mathrm{~A}(\mathrm{H})$ & $\begin{array}{l}\mathrm{A}( \\
\mathrm{L})\end{array}$ & $\begin{array}{l}\mathrm{V}(\mathrm{V} \\
\mathrm{H})\end{array}$ & $\mathrm{O}$ & $\mathrm{O}$ & $\mathrm{O}$ & $\mathrm{V}(\mathrm{VH})$ & $\begin{array}{l}\mathrm{V}(\mathrm{V} \\
\mathrm{H})\end{array}$ & $\mathrm{O}$ & $\mathrm{V}(\mathrm{L})$ & $\mathrm{O}$ & $\mathrm{O}$ \\
\hline$C T$ & $\begin{array}{l}\mathrm{A}( \\
\mathrm{H})\end{array}$ & $\mathrm{V}(\mathrm{H})$ & 1 & $\mathrm{O}$ & $\mathrm{O}$ & $\begin{array}{l}\mathrm{V}(\mathrm{V} \\
\mathrm{H})\end{array}$ & $\mathrm{A}(\mathrm{H})$ & $\mathrm{O}$ & $\begin{array}{l}\mathrm{X}(\mathrm{VH}, \\
\mathrm{VL})\end{array}$ & $\begin{array}{l}\mathrm{V}(\mathrm{V} \\
\mathrm{H})\end{array}$ & $\mathrm{V}(\mathrm{H})$ & $\begin{array}{l}\mathrm{V}(\mathrm{V} \\
\mathrm{H})\end{array}$ & $\begin{array}{l}\mathrm{V}(\mathrm{V} \\
\mathrm{H})\end{array}$ & $\mathrm{V}(\mathrm{L})$ \\
\hline $\begin{array}{l}C U \\
L\end{array}$ & $\mathrm{O}$ & $\mathrm{V}(\mathrm{L})$ & $\mathrm{O}$ & 1 & $\mathrm{~V}(\mathrm{~L})$ & $\mathrm{V}(\mathrm{L})$ & $\mathrm{A}(\mathrm{H})$ & $\mathrm{O}$ & $\mathrm{O}$ & $\mathrm{V}(\mathrm{L})$ & $\mathrm{O}$ & $\mathrm{O}$ & $\mathrm{V}(\mathrm{L})$ & $\mathrm{O}$ \\
\hline $\begin{array}{l}P L \\
C\end{array}$ & $\begin{array}{l}\mathrm{A}( \\
\mathrm{H})\end{array}$ & $\begin{array}{l}\mathrm{A}(\mathrm{V} \\
\mathrm{H})\end{array}$ & $\mathrm{O}$ & $\begin{array}{l}\mathrm{A}( \\
\mathrm{L})\end{array}$ & 1 & $\mathrm{~V}(\mathrm{H})$ & $\mathrm{A}(\mathrm{L})$ & $\mathrm{V}(\mathrm{L})$ & $\mathrm{A}(\mathrm{H})$ & $\mathrm{A}(\mathrm{H})$ & $\begin{array}{l}\mathrm{V}(\mathrm{V} \\
\mathrm{H})\end{array}$ & $\mathrm{V}(\mathrm{L})$ & $\mathrm{A}(\mathrm{H})$ & $\mathrm{O}$ \\
\hline$L P$ & $\begin{array}{l}\mathrm{A}( \\
\mathrm{H})\end{array}$ & $\mathrm{O}$ & $\mathrm{A}(\mathrm{VH})$ & $\begin{array}{l}\mathrm{A}( \\
\mathrm{L})\end{array}$ & $\mathrm{A}(\mathrm{H})$ & 1 & $\mathrm{~A}(\mathrm{VH})$ & $\mathrm{A}(\mathrm{VH})$ & $\mathrm{A}(\mathrm{VH})$ & $\begin{array}{l}\mathrm{A}(\mathrm{V} \\
\mathrm{H})\end{array}$ & $\begin{array}{l}\mathrm{V}(\mathrm{V} \\
\mathrm{H})\end{array}$ & $\mathrm{A}(\mathrm{H})$ & $\begin{array}{l}\mathrm{A}(\mathrm{V} \\
\mathrm{H})\end{array}$ & $\mathrm{V}(\mathrm{L})$ \\
\hline$S C$ & $\mathrm{O}$ & $\mathrm{O}$ & $\mathrm{V}(\mathrm{H})$ & $\begin{array}{l}\text { V( } \\
\mathrm{H})\end{array}$ & $\mathrm{V}(\mathrm{L})$ & $\begin{array}{l}\mathrm{V}(\mathrm{V} \\
\mathrm{H})\end{array}$ & 1 & $\begin{array}{l}\mathrm{X}(\mathrm{VH}, \\
\mathrm{H})\end{array}$ & $\begin{array}{l}\mathrm{X}(\mathrm{VH}, \\
\mathrm{H})\end{array}$ & $\mathrm{V}(\mathrm{H})$ & $\mathrm{V}(\mathrm{L})$ & $\mathrm{V}(\mathrm{H})$ & $\mathrm{O}$ & $\mathrm{O}$ \\
\hline$S T$ & $\mathrm{O}$ & $\mathrm{O}$ & $\mathrm{O}$ & $\mathrm{O}$ & $\mathrm{A}(\mathrm{L})$ & $\begin{array}{l}\mathrm{V}(\mathrm{V} \\
\mathrm{H})\end{array}$ & $\begin{array}{l}\mathrm{X}(\mathrm{H}, \mathrm{V} \\
\mathrm{H})\end{array}$ & 1 & $\mathrm{O}$ & $\mathrm{O}$ & $\mathrm{V}(\mathrm{H})$ & $\mathrm{O}$ & $\mathrm{O}$ & $\mathrm{V}(\mathrm{H})$ \\
\hline$C L$ & $\begin{array}{l}\mathrm{A}( \\
\mathrm{H})\end{array}$ & $\begin{array}{l}\mathrm{A}(\mathrm{V} \\
\mathrm{H})\end{array}$ & $\begin{array}{l}\mathrm{X}(\mathrm{VL}, \\
\mathrm{VH})\end{array}$ & $\mathrm{O}$ & $\mathrm{V}(\mathrm{H})$ & $\begin{array}{l}\mathrm{V}(\mathrm{V} \\
\mathrm{H})\end{array}$ & $\begin{array}{l}\mathrm{X}(\mathrm{H}, \mathrm{V} \\
\mathrm{H})\end{array}$ & $\mathrm{O}$ & 1 & $\begin{array}{l}\mathrm{A}(\mathrm{V} \\
\mathrm{H})\end{array}$ & $\mathrm{A}(\mathrm{L})$ & $\mathrm{A}(\mathrm{L})$ & $\mathrm{A}(\mathrm{L})$ & $\mathrm{V}(\mathrm{L})$ \\
\hline $\begin{array}{l}C O \\
L\end{array}$ & $\begin{array}{l}\mathrm{A}( \\
\mathrm{H})\end{array}$ & $\begin{array}{l}\mathrm{A}(\mathrm{V} \\
\mathrm{H})\end{array}$ & $\mathrm{A}(\mathrm{VH})$ & $\begin{array}{l}\mathrm{A}( \\
\mathrm{L})\end{array}$ & $\mathrm{V}(\mathrm{H})$ & $\begin{array}{l}\mathrm{V}(\mathrm{V} \\
\mathrm{H})\end{array}$ & $\mathrm{A}(\mathrm{H})$ & $\mathrm{O}$ & $\mathrm{V}(\mathrm{VH})$ & 1 & $\begin{array}{l}\mathrm{V}(\mathrm{V} \\
\mathrm{H})\end{array}$ & $\mathrm{V}(\mathrm{H})$ & $\mathrm{V}(\mathrm{L})$ & $\mathrm{V}(\mathrm{H})$ \\
\hline$P E$ & $\begin{array}{l}\mathrm{A}( \\
\mathrm{H})\end{array}$ & $\mathrm{O}$ & $\mathrm{A}(\mathrm{H})$ & $\mathrm{O}$ & $\begin{array}{l}\mathrm{A}(\mathrm{V} \\
\mathrm{H})\end{array}$ & $\begin{array}{l}\mathrm{A}(\mathrm{V} \\
\mathrm{H})\end{array}$ & $\mathrm{A}(\mathrm{L})$ & $\mathrm{A}(\mathrm{H})$ & $\mathrm{V}(\mathrm{L})$ & $\begin{array}{l}\mathrm{A}(\mathrm{V} \\
\mathrm{H})\end{array}$ & 1 & $\mathrm{O}$ & $\mathrm{A}(\mathrm{H})$ & $\begin{array}{l}\mathrm{A}(\mathrm{V} \\
\mathrm{H})\end{array}$ \\
\hline $\begin{array}{l}E S \\
P\end{array}$ & $\begin{array}{l}\mathrm{A}( \\
\mathrm{H})\end{array}$ & $\mathrm{A}(\mathrm{L})$ & $\mathrm{A}(\mathrm{VH})$ & $\mathrm{O}$ & $\mathrm{A}(\mathrm{L})$ & $\mathrm{V}(\mathrm{H})$ & $\mathrm{A}(\mathrm{H})$ & $\mathrm{O}$ & $\mathrm{V}(\mathrm{L})$ & $\mathrm{A}(\mathrm{H})$ & $\mathrm{O}$ & 1 & $\mathrm{O}$ & $\mathrm{V}(\mathrm{H})$ \\
\hline $\begin{array}{l}A D \\
V\end{array}$ & $\begin{array}{l}\text { A( } \\
\text { L) }\end{array}$ & $\mathrm{O}$ & $\mathrm{A}(\mathrm{VH})$ & $\begin{array}{l}\mathrm{A}( \\
\mathrm{L})\end{array}$ & $\mathrm{V}(\mathrm{H})$ & $\begin{array}{l}\mathrm{V}(\mathrm{V} \\
\mathrm{H})\end{array}$ & $\mathrm{O}$ & $\mathrm{O}$ & $\mathrm{V}(\mathrm{L})$ & $\mathrm{A}(\mathrm{L})$ & $\mathrm{V}(\mathrm{H})$ & $\mathrm{O}$ & 1 & $\begin{array}{l}\mathrm{V}(\mathrm{V} \\
\mathrm{H})\end{array}$ \\
\hline$D R$ & $\begin{array}{l}\mathrm{A}( \\
\mathrm{H})\end{array}$ & $\mathrm{O}$ & $\mathrm{A}(\mathrm{L})$ & $\mathrm{O}$ & $\mathrm{O}$ & $\mathrm{A}(\mathrm{L})$ & $\mathrm{O}$ & $\mathrm{A}(\mathrm{H})$ & $\mathrm{A}(\mathrm{L})$ & $\mathrm{A}(\mathrm{H})$ & $\begin{array}{l}\mathrm{V}(\mathrm{V} \\
\mathrm{H})\end{array}$ & $\mathrm{A}(\mathrm{H})$ & $\begin{array}{l}\mathrm{A}(\mathrm{V} \\
\mathrm{H})\end{array}$ & 1 \\
\hline
\end{tabular}

Table 4. The IFRM using LVs

\begin{tabular}{|c|c|c|c|c|c|c|c|c|c|c|c|c|c|c|}
\hline & $T M$ & $P R$ & $C T$ & CUL & $P L C$ & $L P$ & $S C$ & $S T$ & $C L$ & COL & $P E$ & ESP & $A D V$ & $D R$ \\
\hline & 1 & 2 & 3 & 4 & 5 & 6 & 7 & 8 & 9 & 10 & 11 & 12 & 13 & 14 \\
\hline$T M$ & - & NO & $\mathrm{H}$ & NO & $\mathrm{H}$ & $\mathrm{H}$ & $\mathrm{NO}$ & NO & $\mathrm{H}$ & $\mathrm{H}$ & $\mathrm{H}$ & $\mathrm{H}$ & $\mathrm{L}$ & $\mathrm{H}$ \\
\hline$P R$ & $\mathrm{~L}$ & - & NO & NO & $\mathrm{VH}$ & NO & NO & NO & $\mathrm{VH}$ & VH & NO & NO & NO & NO \\
\hline$C T$ & NO & $\mathrm{H}$ & - & NO & NO & VH & NO & NO & VH & $\mathrm{VH}$ & $\mathrm{H}$ & VH & $\mathrm{VH}$ & $\mathrm{L}$ \\
\hline CUL & NO & $\mathrm{L}$ & NO & - & $\mathrm{L}$ & $\mathrm{L}$ & $\mathrm{NO}$ & NO & NO & $\mathrm{L}$ & NO & NO & $\mathrm{L}$ & $\mathrm{NO}$ \\
\hline$P L C$ & NO & NO & NO & NO & - & $\mathrm{H}$ & $\mathrm{NO}$ & $\mathrm{L}$ & NO & NO & $\mathrm{VH}$ & NO & NO & $\mathrm{NO}$ \\
\hline$L P$ & NO & NO & NO & NO & NO & - & $\mathrm{NO}$ & NO & NO & NO & VH & NO & NO & $\mathrm{L}$ \\
\hline$S C$ & NO & NO & $\mathrm{H}$ & $\mathrm{H}$ & $\mathrm{L}$ & $\mathrm{VH}$ & - & VH & VH & $\mathrm{H}$ & $\mathrm{L}$ & $\mathrm{H}$ & NO & NO \\
\hline$S T$ & NO & NO & NO & NO & NO & $\mathrm{VH}$ & $\mathrm{H}$ & - & NO & NO & $\mathrm{H}$ & NO & NO & $\mathrm{H}$ \\
\hline
\end{tabular}


$\begin{array}{lllllllllllllllllllllll}\boldsymbol{C} & \text { NO } & \text { NO } & \text { VL } & \text { NO } & \text { H } & \text { VH } & \text { H } & \text { NO } & - & \text { NO } & \text { NO } & \text { NO } & \text { NO } & \text { L }\end{array}$

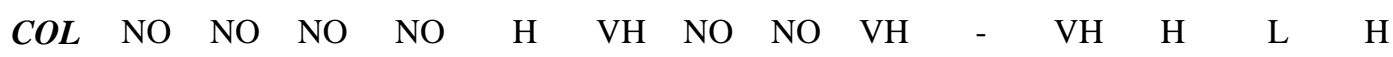

$\begin{array}{llllllllllllll}\boldsymbol{P} & \mathrm{NO} & \mathrm{NO} & \mathrm{NO} & \mathrm{NO} & \mathrm{NO} & \mathrm{NO} & \mathrm{NO} & \mathrm{NO} & \mathrm{L} & \mathrm{NO} & - & \mathrm{NO}\end{array}$

$\begin{array}{lllllllllllllll}\boldsymbol{E S P} & \mathrm{NO} & \mathrm{NO} & \mathrm{NO} & \mathrm{NO} & \mathrm{NO} & \mathrm{H} & \mathrm{NO} & \mathrm{NO} & \mathrm{L} & \mathrm{NO} & \mathrm{NO} & - & \mathrm{NO} & \mathrm{H}\end{array}$

$\begin{array}{lllllllllllllllll}\boldsymbol{A} \boldsymbol{D} & \text { NO } & \text { NO } & \text { NO } & \text { NO } & \text { H } & \text { VH } & \text { NO } & \text { NO } & \text { L } & \text { NO } & \text { H } & \text { NO } & - & \text { VH }\end{array}$

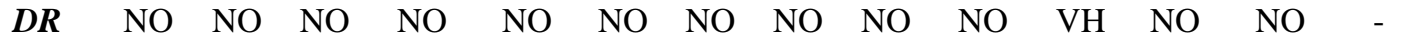

Table 5. The IFRM using Fuzzy number.

\begin{tabular}{|c|c|c|c|c|c|c|c|c|c|c|c|c|c|c|}
\hline- & $T M$ & $P R$ & $C T$ & $\boldsymbol{C U} \boldsymbol{L}$ & $P L C$ & $L P$ & $S C$ & $S T$ & $C L$ & $C O L$ & $P E$ & $E S P$ & $A D V$ & $D R$ \\
\hline $\begin{array}{l}T \\
M\end{array}$ & $\begin{array}{c}(1,1, \\
1,1)\end{array}$ & $\begin{array}{l}(0.00 \\
0.05 \\
0.15 \\
0.25)\end{array}$ & $\begin{array}{l}(0.55 \\
0.65 \\
0.75 \\
0.85)\end{array}$ & $\begin{array}{l}(0.00 \\
0.05 \\
0.15 \\
0.25)\end{array}$ & $\begin{array}{l}(0.55 \\
0.65 \\
0.75, \\
0.85)\end{array}$ & $\begin{array}{c}(0.55 \\
0.65 \\
0.75 \\
0.85)\end{array}$ & $\begin{array}{c}(0.00 \\
0.05 \\
0.15 \\
0.25)\end{array}$ & $\begin{array}{l}(0.00 \\
0.05 \\
0.15 \\
0.25)\end{array}$ & $\begin{array}{l}(0.55 \\
0.65 \\
0.75 \\
0.85)\end{array}$ & $\begin{array}{l}(0.55 \\
0.65 \\
0.75 \\
0.85)\end{array}$ & $\begin{array}{l}(0.55 \\
0.65, \\
0.75 \\
0.85)\end{array}$ & $\begin{array}{l}(0.55 \\
0.65 \\
0.75 \\
0.85)\end{array}$ & $\begin{array}{l}(0.35 \\
0.45 \\
0.55 \\
0.65)\end{array}$ & $\begin{array}{l}(0.55, \\
0.65, \\
0.75, \\
0.85)\end{array}$ \\
\hline $\begin{array}{l}P \\
R\end{array}$ & $\begin{array}{l}(0.35 \\
0.45, \\
0.55 \\
0.65)\end{array}$ & $\begin{array}{c}(1,1, \\
1,1)\end{array}$ & $\begin{array}{l}(0.00 \\
0.05 \\
0.15 \\
0.25)\end{array}$ & $\begin{array}{l}(0.00 \\
0.05, \\
0.15, \\
0.25)\end{array}$ & $\begin{array}{c}(0.75 \\
0.85 \\
0.95 \\
1.00)\end{array}$ & $\begin{array}{l}(0.00 \\
0.05 \\
0.15 \\
0.25)\end{array}$ & $\begin{array}{c}(0.00 \\
0.05 \\
0.15, \\
0.25)\end{array}$ & $\begin{array}{l}(0.00 \\
0.05 \\
0.15 \\
0.25)\end{array}$ & $\begin{array}{l}(0.75 \\
0.85 \\
0.95 \\
1.00)\end{array}$ & $\begin{array}{l}(0.75 \\
0.85 \\
0.95 \\
1.00)\end{array}$ & $\begin{array}{l}(0.00 \\
0.05 \\
0.15 \\
0.25)\end{array}$ & $\begin{array}{l}(0.00 \\
0.05 \\
0.15 \\
0.25)\end{array}$ & $\begin{array}{l}(0.00 \\
0.05 \\
0.15 \\
0.25)\end{array}$ & $\begin{array}{l}(0.00, \\
0.05, \\
0.15, \\
0.25)\end{array}$ \\
\hline $\begin{array}{l}C \\
T\end{array}$ & $\begin{array}{l}(0.00 \\
0.05 \\
0.15 \\
0.25)\end{array}$ & $\begin{array}{l}(0.55 \\
0.65 \\
0.75 \\
0.85)\end{array}$ & $\begin{array}{c}(1,1, \\
1,1)\end{array}$ & $\begin{array}{l}(0.00 \\
0.05 \\
0.15 \\
0.25)\end{array}$ & $\begin{array}{c}(0.00 \\
0.05 \\
0.15 \\
0.25)\end{array}$ & $\begin{array}{c}(0.75 \\
0.85 \\
0.95 \\
1.00)\end{array}$ & $\begin{array}{c}(0.00 \\
0.05 \\
0.15 \\
0.25)\end{array}$ & $\begin{array}{l}(0.00 \\
0.05 \\
0.15 \\
0.25)\end{array}$ & $\begin{array}{l}(0.75 \\
0.85 \\
0.95 \\
1.00)\end{array}$ & $\begin{array}{l}(0.75 \\
0.85 \\
0.95 \\
1.00)\end{array}$ & $\begin{array}{l}(0.55 \\
0.65, \\
0.75, \\
0.85)\end{array}$ & $\begin{array}{l}(0.75 \\
0.85 \\
0.95 \\
1.00)\end{array}$ & $\begin{array}{c}(0.75, \\
0.85 \\
0.95 \\
1.00)\end{array}$ & $\begin{array}{l}(0.35, \\
0.45, \\
0.55, \\
0.65)\end{array}$ \\
\hline $\begin{array}{l}C \\
U \\
L\end{array}$ & $\begin{array}{l}(0.00 \\
0.05 \\
0.15 \\
0.25)\end{array}$ & $\begin{array}{l}(0.35 \\
0.45 \\
0.55 \\
0.65)\end{array}$ & $\begin{array}{l}(0.00 \\
0.05 \\
0.15 \\
0.25)\end{array}$ & $\begin{array}{c}(1,1 \\
1,1)\end{array}$ & $\begin{array}{l}(0.35 \\
0.45 \\
0.55 \\
0.65)\end{array}$ & $\begin{array}{l}(0.35 \\
0.45, \\
0.55 \\
0.65)\end{array}$ & $\begin{array}{l}(0.00 \\
0.05 \\
0.15 \\
0.25)\end{array}$ & $\begin{array}{l}(0.00 \\
0.05 \\
0.15 \\
0.25)\end{array}$ & $\begin{array}{l}(0.00 \\
0.05 \\
0.15 \\
0.25)\end{array}$ & $\begin{array}{l}(0.35 \\
0.45 \\
0.55 \\
0.65)\end{array}$ & $\begin{array}{l}(0.00 \\
0.05 \\
0.15 \\
0.25)\end{array}$ & $\begin{array}{l}(0.00 \\
0.05 \\
0.15 \\
0.25)\end{array}$ & $\begin{array}{l}(0.35 \\
0.45 \\
0.55 \\
0.65)\end{array}$ & $\begin{array}{l}(0.00, \\
0.05, \\
0.15, \\
0.25)\end{array}$ \\
\hline $\begin{array}{l}P \\
L \\
C\end{array}$ & $\begin{array}{l}(0.00 \\
0.05 \\
0.15 \\
0.25)\end{array}$ & $\begin{array}{l}(0.00 \\
0.05 \\
0.15 \\
0.25)\end{array}$ & $\begin{array}{l}(0.00 \\
0.05 \\
0.15 \\
0.25)\end{array}$ & $\begin{array}{l}(0.00 \\
0.05 \\
0.15 \\
0.25)\end{array}$ & $\begin{array}{c}(1,1, \\
1,1)\end{array}$ & $\begin{array}{l}(0.55 \\
0.65 \\
0.75 \\
0.85)\end{array}$ & $\begin{array}{c}(0.00 \\
0.05 \\
0.15 \\
0.25)\end{array}$ & $\begin{array}{l}(0.35 \\
0.45 \\
0.55 \\
0.65)\end{array}$ & $\begin{array}{l}(0.00 \\
0.05 \\
0.15 \\
0.25)\end{array}$ & $\begin{array}{l}(0.00 \\
0.05 \\
0.15 \\
0.25)\end{array}$ & $\begin{array}{l}(0.75 \\
0.85 \\
0.95 \\
1.00)\end{array}$ & $\begin{array}{l}(0.00 \\
0.05 \\
0.15 \\
0.25)\end{array}$ & $\begin{array}{l}(0.00 \\
0.05 \\
0.15 \\
0.25)\end{array}$ & $\begin{array}{l}(0.00, \\
0.05, \\
0.15, \\
0.25)\end{array}$ \\
\hline $\begin{array}{l}L \\
P\end{array}$ & $\begin{array}{l}(0.00 \\
0.05 \\
0.15 \\
0.25)\end{array}$ & $\begin{array}{l}(0.00 \\
0.05 \\
0.15 \\
0.25)\end{array}$ & $\begin{array}{l}(0.00 \\
0.05 \\
0.15 \\
0.25)\end{array}$ & $\begin{array}{l}(0.00 \\
0.05 \\
0.15 \\
0.25)\end{array}$ & $\begin{array}{l}(0.00 \\
0.05 \\
0.15 \\
0.25)\end{array}$ & $\begin{array}{c}(1,1 \\
1,1)\end{array}$ & $\begin{array}{l}(0.00 \\
0.05 \\
0.15 \\
0.25)\end{array}$ & $\begin{array}{l}(0.00 \\
0.05 \\
0.15 \\
0.25)\end{array}$ & $\begin{array}{l}(0.00 \\
0.05 \\
0.15 \\
0.25)\end{array}$ & $\begin{array}{l}(0.00 \\
0.05 \\
0.15 \\
0.25)\end{array}$ & $\begin{array}{l}(0.75 \\
0.85 \\
0.95 \\
1.00)\end{array}$ & $\begin{array}{l}(0.00 \\
0.05 \\
0.15 \\
0.25)\end{array}$ & $\begin{array}{l}(0.00 \\
0.05 \\
0.15 \\
0.25)\end{array}$ & $\begin{array}{l}(0.35 \\
0.45, \\
0.55 \\
0.65)\end{array}$ \\
\hline $\begin{array}{l}S \\
C\end{array}$ & $\begin{array}{l}(0.00 \\
0.05 \\
0.15 \\
0.25)\end{array}$ & $\begin{array}{l}(0.00 \\
0.05 \\
0.15 \\
0.25)\end{array}$ & $\begin{array}{l}(0.55 \\
0.65 \\
0.75 \\
0.85)\end{array}$ & $\begin{array}{l}(0.55 \\
0.65 \\
0.75 \\
0.85)\end{array}$ & $\begin{array}{l}(0.35 \\
0.45 \\
0.55 \\
0.65)\end{array}$ & $\begin{array}{l}(0.75 \\
0.85 \\
0.95 \\
1.00)\end{array}$ & $\begin{array}{c}(1,1, \\
1,1)\end{array}$ & $\begin{array}{l}(0.75 \\
0.85 \\
0.95 \\
1.00)\end{array}$ & $\begin{array}{l}(0.75 \\
0.85 \\
0.95 \\
1.00)\end{array}$ & $\begin{array}{l}(0.55 \\
0.65 \\
0.75 \\
0.85)\end{array}$ & $\begin{array}{l}(0.35 \\
0.45 \\
0.55 \\
0.65)\end{array}$ & $\begin{array}{l}(0.55 \\
0.65 \\
0.75 \\
0.85)\end{array}$ & $\begin{array}{l}(0.00 \\
0.05 \\
0.15 \\
0.25)\end{array}$ & $\begin{array}{l}(0.00, \\
0.05, \\
0.15, \\
0.25)\end{array}$ \\
\hline $\begin{array}{l}S \\
T\end{array}$ & $\begin{array}{l}(0.00 \\
0.05 \\
0.15 \\
0.25)\end{array}$ & $\begin{array}{l}(0.00 \\
0.05 \\
0.15 \\
0.25)\end{array}$ & $\begin{array}{l}(0.00 \\
0.05 \\
0.15 \\
0.25)\end{array}$ & $\begin{array}{c}(0.00 \\
0.05 \\
0.15 \\
0.25)\end{array}$ & $\begin{array}{l}(0.00 \\
0.05 \\
0.15 \\
0.25)\end{array}$ & $\begin{array}{l}(0.75 \\
0.85 \\
0.95 \\
1.00)\end{array}$ & $\begin{array}{l}(0.55 \\
0.65 \\
0.75 \\
0.85)\end{array}$ & $\begin{array}{c}(1,1, \\
1,1)\end{array}$ & $\begin{array}{l}(0.00 \\
0.05 \\
0.15 \\
0.25)\end{array}$ & $\begin{array}{l}(0.00 \\
0.05 \\
0.15 \\
0.25)\end{array}$ & $\begin{array}{l}(0.55 \\
0.65 \\
0.75 \\
0.85)\end{array}$ & $\begin{array}{l}(0.00 \\
0.05 \\
0.15 \\
0.25)\end{array}$ & $\begin{array}{l}(0.00 \\
0.05 \\
0.15 \\
0.25)\end{array}$ & $\begin{array}{l}(0.55, \\
0.65, \\
0.75, \\
0.85)\end{array}$ \\
\hline $\begin{array}{l}C \\
L\end{array}$ & $\begin{array}{l}(0.00 \\
0.05 \\
0.15 \\
0.25)\end{array}$ & $\begin{array}{l}(0.00 \\
0.05 \\
0.15 \\
0.25)\end{array}$ & $\begin{array}{l}(0.15 \\
0.25 \\
0.35 \\
0.45)\end{array}$ & $\begin{array}{l}(0.00 \\
0.05 \\
0.15 \\
0.25)\end{array}$ & $\begin{array}{c}(0.55 \\
0.65 \\
0.75 \\
0.85)\end{array}$ & $\begin{array}{c}(0.75 \\
0.85 \\
0.95 \\
1.00)\end{array}$ & $\begin{array}{l}(0.55 \\
0.65 \\
0.75 \\
0.85)\end{array}$ & $\begin{array}{l}(0.00 \\
0.05 \\
0.15 \\
0.25)\end{array}$ & $\begin{array}{c}(1,1, \\
1,1)\end{array}$ & $\begin{array}{l}(0.00 \\
0.05 \\
0.15 \\
0.25)\end{array}$ & $\begin{array}{l}(0.00 \\
0.05 \\
0.15 \\
0.25)\end{array}$ & $\begin{array}{c}(0.00 \\
0.05 \\
0.15 \\
0.25)\end{array}$ & $\begin{array}{c}(0.00 \\
0.05 \\
0.15 \\
0.25)\end{array}$ & $\begin{array}{l}(0.35, \\
0.45, \\
0.55, \\
0.65)\end{array}$ \\
\hline $\begin{array}{l}C \\
O \\
L\end{array}$ & $\begin{array}{l}(0.00 \\
0.05 \\
0.15 \\
0.25)\end{array}$ & $\begin{array}{l}(0.00 \\
0.05 \\
0.15 \\
0.25)\end{array}$ & $\begin{array}{l}(0.00 \\
0.05 \\
0.15 \\
0.25)\end{array}$ & $\begin{array}{l}(0.00, \\
0.05, \\
0.15, \\
0.25)\end{array}$ & $\begin{array}{c}(0.55 \\
0.65, \\
0.75, \\
0.85)\end{array}$ & $\begin{array}{l}(0.75, \\
0.85, \\
0.95 \\
1.00)\end{array}$ & $\begin{array}{c}(0.00, \\
0.05, \\
0.15, \\
0.25)\end{array}$ & $\begin{array}{l}(0.00 \\
0.05 \\
0.15 \\
0.25)\end{array}$ & $\begin{array}{l}(0.75 \\
0.85 \\
0.95 \\
1.00)\end{array}$ & $\begin{array}{l}(1,1, \\
1,1)\end{array}$ & $\begin{array}{l}(0.75, \\
0.85 \\
0.95 \\
1.00)\end{array}$ & $\begin{array}{l}(0.55 \\
0.65 \\
0.75 \\
0.85)\end{array}$ & $\begin{array}{l}(0.35, \\
0.45, \\
0.55, \\
0.65)\end{array}$ & $\begin{array}{c}(0.55, \\
0.65, \\
0.75, \\
0.85)\end{array}$ \\
\hline
\end{tabular}




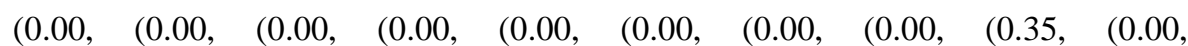

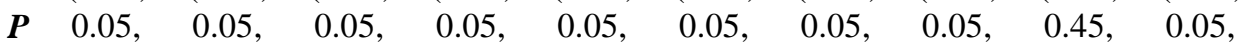

$\boldsymbol{E} \quad 0.15, \quad 0.15, \quad 0.15, \quad 0.15, \quad 0.15, \quad 0.15, \quad 0.15, \quad 0.15, \quad 0.55, \quad 0.15$,

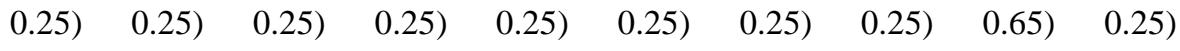

$(0.00, \quad(0.00, \quad(0.00, \quad(0.00, \quad(0.00, \quad(0.55, \quad(0.00, \quad(0.00, \quad(0.35, \quad(0.00, \quad(0.00$,

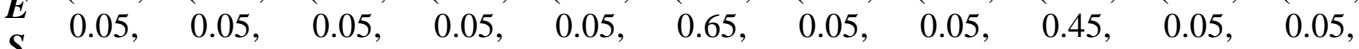

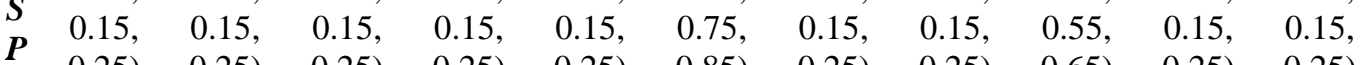

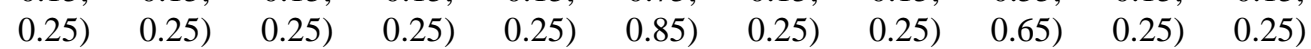

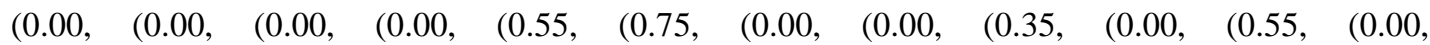

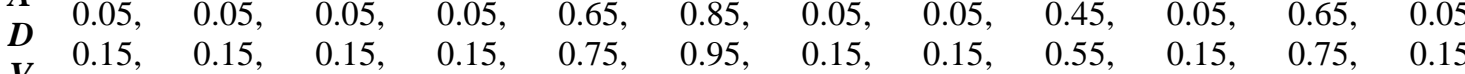

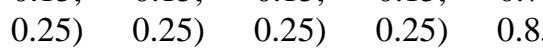

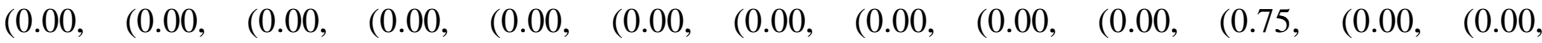

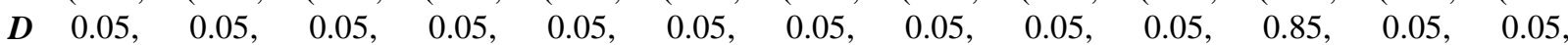

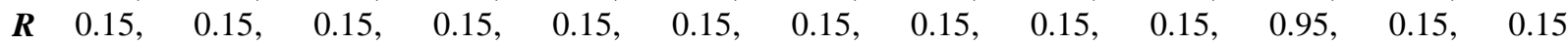

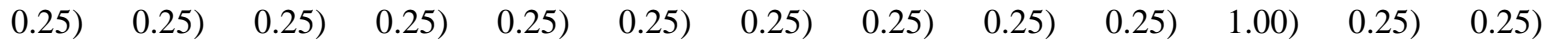

$(0.00, \quad(0.00, \quad(0.00$

0.05

$(0.00, \quad(0.55$

$0.05, \quad 0.65$,

$0.75, \quad 0.75$

$0.25) \quad 0.85)$

$(0.75$,

$(1,1, \quad 0.85$,

1, 1) $\quad 0.95$,

1.00)

$(1,1$,

$1,1)$

Table 6. Final defuzzified reachability matrix with transitive links

\begin{tabular}{|c|c|c|c|c|c|c|c|c|c|c|c|c|c|c|c|c|}
\hline $\begin{array}{l}\text { Impact of } \mathbf{i} \\
\quad \text { on } \mathbf{j}\end{array}$ & & $T M$ & $P R$ & $C T$ & $C U L$ & $P L C$ & $L P$ & $S C$ & $S T$ & $C L$ & COL & $P E$ & ESP & $A D V$ & $D R$ & $\begin{array}{c}\text { Driving } \\
\text { Power }\end{array}$ \\
\hline & & 1 & 2 & 3 & 4 & 5 & 6 & 7 & 8 & 9 & 10 & 11 & 12 & 13 & 14 & \\
\hline$T M$ & 1 & 1 & 0 & 1 & 0 & 1 & 1 & 0 & 0 & 1 & 1 & 1 & 1 & 1 & 1 & 10 \\
\hline$P R$ & 2 & 1 & 1 & $1^{*}$ & 0 & 1 & $1^{*}$ & $1^{*}$ & 0 & 1 & 1 & $1^{*}$ & 1 & $1^{*}$ & $1^{*}$ & 12 \\
\hline$C T$ & 3 & 0 & 1 & 1 & 0 & $1^{*}$ & 1 & $1^{*}$ & 0 & 1 & 1 & 1 & 1 & 1 & 1 & 11 \\
\hline CUL & 4 & 0 & 1 & 0 & 1 & 1 & 1 & 0 & $1^{*}$ & $1^{*}$ & 1 & $1^{*}$ & $1^{*}$ & 1 & $1^{*}$ & 11 \\
\hline$P L C$ & 5 & 0 & 0 & 0 & 0 & 1 & 1 & $1^{*}$ & 1 & $1^{*}$ & 0 & 1 & 1 & 0 & $1^{*}$ & 8 \\
\hline$L P$ & 6 & 0 & 0 & 0 & 0 & 0 & 1 & 0 & 0 & $1^{*}$ & 0 & 1 & 0 & 0 & 1 & 4 \\
\hline$S C$ & & 0 & $1^{*}$ & 1 & 1 & 1 & 1 & 1 & 1 & 1 & 1 & 1 & 1 & $1^{*}$ & $1^{*}$ & 13 \\
\hline$S T$ & 7 & 0 & 0 & $1^{*}$ & $1^{*}$ & $1^{*}$ & 1 & 1 & 1 & $1^{*}$ & $1^{*}$ & 1 & $1^{*}$ & 0 & 1 & 11 \\
\hline$C L$ & 8 & 0 & $1^{*}$ & 1 & $1^{*}$ & 1 & 1 & 1 & $1^{*}$ & 1 & $1^{*}$ & $1^{*}$ & $1^{*}$ & $1^{*}$ & 1 & 13 \\
\hline COL & 9 & 0 & 0 & $1^{*}$ & 0 & 1 & 1 & $1^{*}$ & $1^{*}$ & 1 & 1 & 1 & 1 & 1 & 1 & 11 \\
\hline$P E$ & 10 & 0 & 0 & $1^{*}$ & 0 & $1^{*}$ & $1^{*}$ & $1^{*}$ & 0 & 1 & 0 & 1 & 0 & 0 & $1^{*}$ & 7 \\
\hline$E S P$ & 11 & 0 & 0 & $1^{*}$ & 0 & $1^{*}$ & 1 & $1^{*}$ & 0 & 1 & 0 & $1^{*}$ & 1 & 0 & 1 & 8 \\
\hline$A D V$ & 12 & 0 & 0 & $1^{*}$ & 0 & $1^{*}$ & 1 & 0 & $1^{*}$ & 1 & 0 & 1 & $1^{*}$ & 1 & 1 & 9 \\
\hline$D R$ & 13 & 0 & 0 & 0 & 0 & 0 & 0 & 0 & 0 & 0 & 0 & 1 & 0 & 0 & 1 & 2 \\
\hline Dependence & 14 & 2 & 5 & 10 & 4 & 12 & 13 & 9 & 7 & 13 & 8 & 14 & 11 & 8 & 14 & 130 \\
\hline
\end{tabular}

* Transitivity check

Table 7. Level partitioning of Characteristics

\begin{tabular}{lcccc}
\hline $\begin{array}{c}\text { Enable } \\
\text { rs }\end{array}$ & Reachability set & Antecedent & Intersetion set & $\begin{array}{c}\text { Leve } \\
\mathbf{l}\end{array}$ \\
\hline$T M$ & $1,3,5,6,9,10,11,12,13,14$ & 1,2 & 1 & $\mathrm{~V}$ \\
\hline
\end{tabular}


INTERNATIONAL JOURNAL OF CIRCUITS, SYSTEMS AND SIGNAL PROCESSING

\begin{tabular}{|c|c|c|c|c|}
\hline$P R$ & $1,2,3,5,6,7,9,10,11,12,13$ & $2,3,4,7,9$ & $2,3,7,9$ & VI \\
\hline$C T$ & $2,3,5,6,7,9,10,11,12,13,14$ & $1,2,3,7,8,9,10,11,12,13$ & $2,3,7,9,10,11,12$ & $\mathrm{~V}$ \\
\hline$C U L$ & $2,4,5,6,8,9,10,11,12,13,14$ & $4,7,8,9$ & $4,8,9$ & $\mathrm{~V}$ \\
\hline$P L C$ & $5,6,7,8,9,11,12,14$ & $1,2,3,4,5,7,8,9,10,11,12,13$ & $5,7,8,9,11,12$ & III \\
\hline$L P$ & $6,9,11,14$ & $\begin{array}{c}1,2,3,4,5,6,7,8,9,10,11,12 \\
13\end{array}$ & $6,9,11$ & II \\
\hline$S C$ & $\begin{array}{c}2,3,4,5,6,7,8,9,10,11,12 \\
13,14\end{array}$ & $2,3,5,7,8,9,10,11,12$ & $2,3,5,7,8,9,10,11,12$ & $\mathrm{~V}$ \\
\hline$S T$ & $3,4,5,6,7,8,9,10,11,12,14$ & $4,5,7,8,9,10,13$ & $4,5,7,8,9,10$ & IV \\
\hline$C L$ & $\begin{array}{c}2,3,4,5,6,7,8,9,10,11,12 \\
13,14\end{array}$ & $\begin{array}{c}1,2,3,4,5,6,7,8,9,10,11,12 \\
13\end{array}$ & $\begin{array}{c}2,3,4,5,6,7,8,9,10,11 \\
12,13\end{array}$ & $\mathrm{~V}$ \\
\hline$C O L$ & $3,5,6,7,8,9,10,11,12,13,14$ & $1,2,3,4,7,8,9,10$ & $3,7,8,9,10$ & $\mathrm{~V}$ \\
\hline$P E$ & $3,5,6,7,9,11,14$ & $\begin{array}{c}1,2,3,4,5,6,7,8,9,10,11,12 \\
13,14\end{array}$ & $3,5,6,7,9,11,14$ & II \\
\hline$E S P$ & $3,5,6,7,9,11,12,14$ & $1,2,3,4,5,7,8,9,10,12,13$ & $3,5,7,9,12$ & III \\
\hline$A D V$ & $3,5,6,8,9,11,12,13,14$ & $1,2,3,4,7,9,10,13$ & $3,9,13$ & IV \\
\hline$D R$ & 11,14 & $\begin{array}{c}1,2,3,4,5,6,7,8,9,10,11,12 \\
13,14\end{array}$ & 11,14 & I \\
\hline
\end{tabular}

Table 8. Fuzzy Values and Final CVs of dependence and driving power

\begin{tabular}{lcccc}
\hline & Dependence (Fuzzy Value) & Dependence $(\mathbf{C V})$ & Driving (Fuzzy Value) & Driving power $(\mathbf{C V})$ \\
\hline $\boldsymbol{T M}$ & $(1.35,2.05,3.35,4.65)$ & 2.7667 & $(5.75,6.85,8.15,9.45)$ & 7.5222 \\
$\boldsymbol{P R}$ & $(6.55,7.65,8.95,10.05)$ & 8.3000 & $(3.6,4.45,5.75,6.9)$ & 5.1333 \\
$\boldsymbol{C} \boldsymbol{T}$ & $(2.25,3.05,4.35,5.65)$ & 3.7556 & $(6.2,7.25,8.55,9.6)$ & 7.9000 \\
$\boldsymbol{C U} \boldsymbol{L}$ & $(1.55,2.25,3.55,4.85)$ & 2.9667 & $(2.75,3.65,4.95,6.25)$ & 4.3444 \\
$\boldsymbol{P L C}$ & $(4.65,5.65,6.95,8.2)$ & 6.3278 & $(2.65,3.45,4.75,6)$ & 4.1500 \\
$\boldsymbol{L P}$ & $(7.5,8.65,9.95,10.95)$ & 9.2833 & $(2.1,2.85,4.15,5.4)$ & 3.5556 \\
$\boldsymbol{S C}$ & $(2.1,2.85,4.15,5.45)$ & 3.5611 & $(6.15,7.25,8.55,9.7)$ & 7.9056 \\
$\boldsymbol{S} \boldsymbol{T}$ & $(2.1,2.85,4.15,5.4)$ & 3.5556 & $(3.4,4.25,5.55,6.8)$ & 4.9444 \\
$\boldsymbol{C L}$ & $(5.6,6.65,7.95,9.05)$ & 7.3056 & $(3.35,4.25,5.55,6.8)$ & 4.9389 \\
$\boldsymbol{C O L}$ & $(3.95,4.85,6.15,7.35)$ & 5.5333 & $(5.25,6.25,7.55,8.7)$ & 6.9167 \\
$\boldsymbol{P E}$ & $(6.55,7.65,8.95,10.05)$ & 8.3000 & $(1.35,2.05,3.35,4.65)$ & 2.7667 \\
$\boldsymbol{E S P}$ & $(3.4,4.25,5.55,6.8)$ & 4.9444 & $(2.45,3.25,4.55,5.85)$ & 3.9556 \\
$\boldsymbol{A D V}$ & $(2.8,3.65,4.95,6.2)$ & 4.3444 & $(3.95,4.85,6.15,7.35)$ & 5.5333 \\
$\boldsymbol{D} \boldsymbol{R}$ & $(5,6.05,7.35,8.6)$ & 6.7222 & $(1.75,2.45,3.75,5)$ & 3.1611 \\
\hline
\end{tabular}




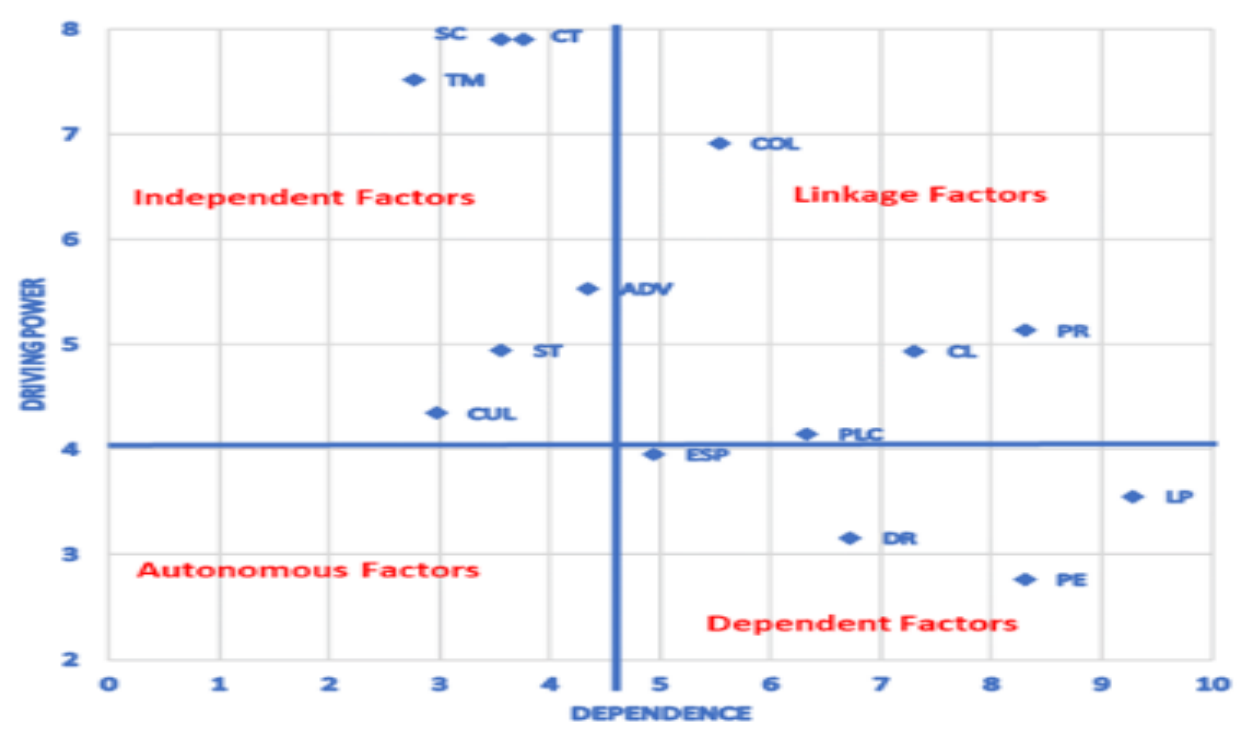

Figure 5. FMICMAC analysis

According to the results oriented from the MICMAC method, the factors will be framed into 4 clusters with different significance characteristics based on the degree of orientation and the degree of dependence of the factors in the considered LO relationship. With simultaneous characteristics strong Dr and weak De powers, Cluster IV is focused on the most because of its importance. The factors belonging to this cluster are highly independent, namely ST, SC, CT, TM, ADV, CUL. When the values in this cluster change, it will greatly affect the change of the elements in the dependent cluster and then in the LO relationship. Therefore, these Factors must be considered in the process of developing a sustainable relationship in LO.

In contrast, cluster II contains factors with highly dependent power. Therefore, as mentioned, the factors in this cluster will be impacted largely by the change of factors in cluster IV. Specifically, factors including ESP, DR, PE and LP will not be focused because their dependence will also be reduced in importance in the process of building solutions to improve the LO relationship. Therefore, we will not also consider these factors as the input data for FAHP method.

The remaining two clusters in the profiling of 4-cluster MICMAC carry an intermediate meaning between the level of independence (cluster IV) and dependence (Cluster II). In this paper, cluster I - autonomous factors does not contain any factors, therefore, there is no factor in this cluster to be input for FAHP analysis in the next step. Meanwhile, Cluster III Linkage has the same activation as Cluster II - Dependent Factors, with four enabling factors. Cluster III - Linking factors is an important link to form supporting factors in Cluster II, extremely important to build a strong relationship including CL, PR, COL, PLC. When the factors in this cluster III change, there will also be a specific level of impact on the change in the impact value of the factors in cluster II, then on the LO relationship.

From the results formed from the FMICMAC method, the group of 10 factors in clusters III and IV will be redefined according to the display characteristics to make the analysis clearer. Specifically, cluster III and cluster IV will be identified as The Operating factors and The Creating Factors clusters, respectively. A diagram describing the characteristics that are input to the FAHP method is shown in Figure 6.

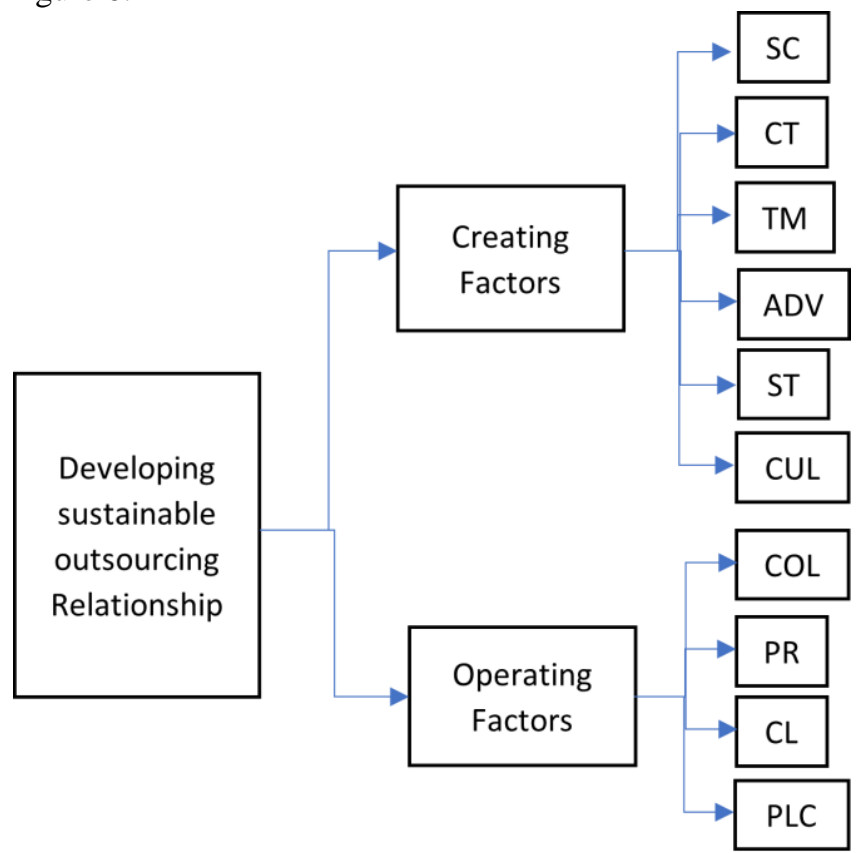

Figure 6. AHP model

\section{B. Using FAHP with the integration of FISM-FMICMAC method}

According to the results from FISM-FMICMAC, the factors to develop the FAHP. The integrated methodology with FAHP's flow chart is given in Figure 3.

In this study, the FAHP that is shown by Do et al. (2015) [85], which will be enlarged to make the solution for our model as follows:

- Step 1: Developing the Hierarchical Structure (HS) of the evaluation index system.

+ The HS is built by combining all the criteria and attributes to the results of FISM-FMICMAC analysis. Specifically, the factors in Cluster IV Independent Factors is considered as Creating 
Factors because this cluster have a strong driving power more than others. The remaining clusters are also named as Operating and Internal Clusters for Cluster III and Cluster II, respectively. The attributes which belong to factors according to their common enablers, are still dissected though these enablers are in one Cluster. The specific HS in this step is depicted in Figure 6.

- Step 2: Determining the LVs and fuzzy conversion scale. $+\quad$ Although fuzzy linguistics numbers are existed in the above FISM-FMICMAC methodology, the other fuzzy scales must be used because of the FAHP requirements. However, the Table 4's results will be still used instead of the other surveys must perform one more time which presented in the reviewed articles. In this study, the fuzzy are given in Table 9 Saaty (1990), Natasa and Zivojin (2017) [91]

Table 9. Rating scale for measuring mutual importance of criteria or alternatives

\begin{tabular}{ccccc}
\hline & Fuzzy number & \multicolumn{2}{c}{ Reciprocal fuzzy number } & Linguistic value \\
\hline$\widetilde{\mathbf{1}}$ & $(1,1,1.5,2)$ & $\tilde{1}^{-1}$ & $(1 / 2,1 / 1.5,1,1)$ & Equally significant \\
$\widetilde{\mathbf{3}}$ & $(2,2.5,3.5,4)$ & $\tilde{3}^{-1}$ & $(1 / 4,1 / 3.5,1 / 2.5,1 / 2)$ & Slightly significant \\
$\widetilde{\mathbf{5}}$ & $(4,4.5,5.5,6)$ & $\tilde{\mathbf{5}}^{-1}$ & $(1 / 6,1 / 5.5,1 / 4.5,1 / 4)$ & Very significant \\
$\widetilde{\mathbf{7}}$ & $(6,6.5,7.5,8)$ & $\tilde{7}^{-1}$ & $(1 / 8,1 / 7.5,1 . / 6.5,1 / 6)$ & Greatly significant \\
$\widetilde{\mathbf{9}}$ & $(8,8.5,9,9)$ & $\tilde{9}^{-1}$ & $(1 / 9,1 / 9,1 / 8.5,1 / 8)$ & Absolutely significant \\
$\widetilde{\mathbf{2}} \widetilde{\mathbf{4}}, \widetilde{\mathbf{6}}, \widetilde{\mathbf{8}}$ intermediate values & $(x-1, x-0.5, x+0.5, x+1)$ & \\
\hline
\end{tabular}

Source: [137].

- Step 3: Building comparison matrices.

+ In this step, $n$ attributes in one level, where the relative importance of attribute $\mathrm{i}$ to $\mathrm{j}$ is represented by TFNs $\widetilde{a_{\imath j}}=\left(l_{i j}, m_{i j}, n_{i j}, u_{i j}\right)$. If attribute $\mathrm{i}$ is greatly significant in comparison with the attribute $\mathrm{j}$; $\widetilde{a_{l \jmath}}=(6,6.5,7.5,8)$ and vice versa, reciprocally TFN $\widetilde{a_{l \jmath}}=(1 / 8,1 / 7.5,1 . / 6.5,1 / 6)$. In this step, the pairwise comparisons of the enablers in first level 1 , which consists of Creating Factors and Operating Factors, are established after we discussed with the experts one more time. Besides, to reduce subjective level of data, we have re-analyzed the results from Table 4. Meanwhile, the pairwise comparisons of the enablers belonging to level 2, which is the level 1's sub, are completely used from Table 4 . The pairwise comparisons of the enablers have been shown in the Table10-12.

Table 10 Pairwise comparison in level 1

\begin{tabular}{ccc}
\hline Factors & Creating Factors & Operating Factors \\
\hline Creating Factors & 1 & $(6,13 / 2,15 / 2,8)$ \\
Operating Factors & $(1 / 8,2 / 15,2 / 13,1 / 6)$ & 1 \\
\hline
\end{tabular}

- Step 4: Calculating CR of comparison matrix. The CR is computed following function (6) Saaty (1980) [83]:

$$
C R=\frac{C I}{R I(n)} \text {. }
$$

where:

+ Consistency Index (CI) for comparison matrix, can be calculated with the use of the function (7) [123] when $\lambda_{\max }$ is the largest eigenvalue of the CM, $n$ is the dimension of the matrix.

$$
C I=\frac{\lambda_{\max }-n}{n-1} \text {. }
$$

$+\quad R I(n)$ is a random index Golden (1989) that depends on $n$, as shown in Table 13.[92]

The CR is equal to or less than 0.1 , it can be acceptable. In this study, all CR values are acceptable, the calculation process is turned to next step.

- Step 5: Calculate the attributes' local weights (LCW).

+ Crisp relative importance weight (priority vectors) for factors is computed by modifying the approach that is used in Chang (1996) [93]. Now we can use this new approach to find the synthetic extent values [18] of each factor. A TFN was denoted as $\widetilde{a_{\imath j}}=$ $\left(l_{i j}, m_{i j}, n_{i j}, u_{i j}\right)$ is defuzzified to a crisp number as function (5).

+ The significant step in FAHP is forming a hierarchical structure of factors and sub factors which are specific to the research problem. The method of 'Aggregation of Individual Judgements' (AIJ) is used here. In this method a single judgement matrix is obtained from a group of judgement matrix and using this single matrix the weights of factors are found. AIJ is performed using Arithmetic mean operations. Suppose there are k experts on the panel of decision makers. Then for the comparison of $i^{t h}$ factor and $j^{t h}$ factor, we will have $k$ comparison matrices and compiling these matrices we obtain a 
single judgement matrix Synthetic extent value of $i^{\text {th }}$ factor $S_{i}$ is defined as follow:

$$
A=\left[\begin{array}{cccc}
l_{i j 1} & m_{i j 1} & n_{i j 1} & u_{i j 1} \\
l_{i j 2} & l_{i j 2} & \ldots & u_{i j 2} \\
\ldots & \ldots & \ldots & \ldots \ldots \\
l_{i j k} & m_{i j k} & n_{i j k} & u_{i j k}
\end{array}\right] .
$$

where $1 \leq j \leq n, 1 \leq i \leq n$ and $k$ is number of experts.

+ Arithmetic mean operation is used for aggregation.

$$
\begin{aligned}
& \left(l_{i j}, m_{i j}, n_{i j}, u_{i j}\right)= \\
& \left(\frac{l_{i j 1}+\cdots+l_{i j k}}{k}, \frac{m_{i j 1}+\cdots+m_{i j k}}{k}, \frac{n_{i j 1}+\cdots+n_{i j k}}{k}, \frac{u_{i j 1}+\cdots+u_{i j k}}{k}\right)
\end{aligned}
$$

$+\quad$ Now we can use extent analysis method to find the synthetic extent values Zarandi et al. (2012) [94] of each factor, $S_{i}$ from functions (9) to (12).

$$
\begin{aligned}
& S_{i}=\sum_{j=1}^{n} M_{i j} *\left(\sum_{i=1}^{n} \sum_{j=1}^{n} M_{i j}\right)^{-1} \text {. } \\
& \text { where: } \\
& \sum_{j=1}^{n} M_{i j}= \\
& \left(l_{i 1}+\ldots+l_{i n}, m_{i 1}+\ldots+m_{i n}, n_{i 1}+\ldots+n_{i n}, u_{i 1}+\ldots+u_{i n}\right)= \\
& \left(l_{i}, m_{i}, n_{i}, u_{i}\right), \forall i=1,2, \ldots, n \text {. } \\
& \sum_{i=1}^{n} \sum_{j=1}^{n} M_{i j}= \\
& \left(l_{1}+\ldots+l_{n}, m_{1}+\ldots+m_{n}, n_{1}+\ldots+n_{n}, u_{1}+\ldots+u_{n}\right)= \\
& (l, m, n, u) \text {. } \\
& \left(\sum_{i=1}^{n} \sum_{j=1}^{n} M_{i j}\right)^{-1}=\left(\frac{1}{u}, \frac{1}{n}, \frac{1}{m}, \frac{1}{l}\right) \text {. } \\
& V\left(S_{i} \geq S_{j}\right)=\left\{\begin{array}{lc}
1 & f \geq b \\
0 & b-g>h+a \\
\frac{g-b+h+a}{h+a} & 0<b-g<h+a \\
\frac{b-g+h+a}{h+a} & b-g<h+a, \text { where } b<g
\end{array}\right.
\end{aligned}
$$

where $S_{i}=(e, f, g, h)$ và $S_{j}=(a, b, c, d)$

+ Final weightage of each of the factors can be calculated by calculating the average of $V\left(S_{i} \geq S_{j}\right)$ and then normalizing the obtained values.

Therefore, substituting pairwise comparison of the enabler in Tables 11-12 into the functions (8)-(13) will help determine the weights of the attributes in the specific respective order as follows:

+ From table 10, we calculate $\sum_{j=1}^{n} M_{i j}$ as follows:

$$
\begin{aligned}
& A_{1}=(7 ; 7.5 ; 8.5 ; 9), \\
& A_{2}=(1.125 ; 1.1333 ; 1.1538 ; 1.1667),
\end{aligned}
$$

Then $\sum_{i=1}^{n} \sum_{j=1}^{n} M_{i j}=$

(8.125; 8.6333; 9.6538; 10.1667).

$$
\left(\sum_{i=1}^{n} \sum_{j=1}^{n} M_{i j}\right)^{-1}=
$$

(0.1231; 0.1158; 0.1036; 0.0984).

Then we calculate the synthetic extent values of each of the factors as follows:

$$
\begin{aligned}
& S_{1}=(0.8615 ; 0.9231 ; 1.0462 ; 1.1077), \\
& S_{2}=(0.1385 ; 0.1395 ; 0.142 ; 0.1436),
\end{aligned}
$$

Then $V\left(S_{i} \geq S_{j}\right)$ is computed and obtained the following result:

$$
\begin{aligned}
& V\left(S_{1} \geq S_{j}\right)=1 \text { for every } j \neq 1 . \\
& V\left(S_{2} \geq S_{j}\right)=0,2229 \text { for every } j \neq 2 .
\end{aligned}
$$

On normalizing we get the weightage of each factor.
Weight $\left(A_{1}\right)=0.81772$,

Weight $\left(A_{2}\right)=0.18228$.

So, we prioritize the factors in the first stage consisting of Creating and Operating Factors which affect the LO relationship directly. These factors are determined by two clusters in FMICMAC.

+ According to Cluster IV - Independent Factors which consists of Creating Factors (System compliance (1); Commitment or trust (2); Top management support (3); TQM and JIT supplier added (4); Standardization (5); and Culture (6)), we have determined the calculation process as similar as follows:

$$
\begin{aligned}
& A_{1}=(23 ; 24.7 ; 28 ; 30) \\
& A_{2}=(12.125 ; 12.6333 ; 14.6515 ; 16.1667), \\
& A_{3}=(6 ; 6.8333 ; 9.5 ; 11) \\
& A_{4}=(3.8611 ; 4.0635 ; 5.5176 ; 6.625) \\
& A_{5}=(3.6111 ; 4.1111 ; 5.6176 ; 6.125), \\
& A_{6}=(3.125 ; 3.8 ; 5.1515 ; 5.1667)
\end{aligned}
$$

Then, the synthetic extent values of each of the factors will be as follows:

$$
\begin{aligned}
& S_{1}=(0.4447 ; 0.4776 ; 0.5414 ; 0.58), \\
& S_{2}=(0.1184 ; 0.1282 ; 0.1769 ; 0.2159), \\
& S_{3}=(0.116 ; 0.1321 ; 0.1837 ; 0.2127), \\
& S_{4}=(0.0747 ; 0.0786 ; 0.1067 ; 0.1281), \\
& S_{5}=(0.0698 ; 0.0795 ; 0.1086 ; 0.1184), \\
& S_{6}=(0.0604 ; 0.0735 ; 0.0996 ; 0.0999) .
\end{aligned}
$$

Then the values of $V\left(S_{i} \geq S_{j}\right)$ are resulted as follows:

$$
\begin{aligned}
& V\left(S_{1} \geq S_{j}\right)=1 \text { for every } j \neq 1, \\
& V\left(S_{2} \geq S_{j}\right)=0.5449 \text { for every } j \neq 2, \\
& V\left(S_{3} \geq S_{j}\right)=0.5529 \text { for every } j \neq 3, \\
& V\left(S_{4} \geq S_{j}\right)=0.3525 \text { for every } j \neq 4, \\
& V\left(S_{5} \geq S_{j}\right)=0,3448 \text { for every } j \neq 5, \\
& V\left(S_{6} \geq S_{j}\right)=0,306 \text { for every } j \neq 6 .
\end{aligned}
$$

On normalizing we get the weightage of each factor.

Weight $\left(A_{1}\right)=0.3225$,

Weight $\left(A_{2}\right)=0.1757$,

Weight $\left(A_{3}\right)=0.1783$,

Weight $\left(A_{4}\right)=0.1137$,

Weight $\left(A_{5}\right)=0.11122$,

Weight $\left(A_{6}\right)=0.0987$.

+ In the same way, the weightage of each factor in Cluster III - Linkage Factors that consists of Creating Factors (Buyer-3PL Collaboration (1); Guanxi (Personal Relationships) (2); Contract length (3); 3PL Customer Service Expertise (4)) have been also determined as follows:

$$
\begin{aligned}
& \text { Weight }\left(A_{1}\right)=0.6098 \\
& \text { Weight }\left(A_{2}\right)=0.1567 \\
& \text { Weight }\left(A_{3}\right)=0.1307 \\
& \text { Weight }\left(A_{4}\right)=0.1028
\end{aligned}
$$

- Step 6: Calculating the Global Weights (GW) for the attributes.

$+\mathrm{GW}$ are calculated after the relationships between LCW are determined. In FAHP, GW is equal to the result when the LCW of the attribute is multiplied with the LCW of the criterion to which it belongs.

+ In this step, global weights derived from FAHP have significantly influenced to the description about the 
significance of the enablers for increasing the sustainable degree in LO relationships. These weights will be displayed the most complete next to the normalizing weights in Table 14. According to Table 14 , System compliance $(0.2637-1)$ came at rank one out of ten enables, whose global weight was $70 \%$ more than rank two enabler, Top management support (0.1458-2). Commitment or trust (0.1437-3) and Buyer-3PL Collaboration (0.1112-4) were at rank three and four. The remaining enablers have been ranked from five to ten which consisted of TQM and JIT supplier added (added distinctive value) (0.0929-5); Standardization (0.0909-6); Culture (0.0807-7); Guanxi (Personal Relationships) (0.0286-8); Contract length (0.0238-9); and 3PL Customer Service Expertise (0.0187-10), respectively.

This study was inherited from many variables which work as enablers in the orientation of sustainability in LO relationships. By linking the above proposed model with the LO relationship management process, the strategy makers will have a robust base on considering the importance of the enablers in the process of decision-making in each of the specific segment, which help to achieve high efficiency in logistics operations.

The case study of Mekong Delta, Vietnam, describes the reality of using the integrated FISM-FMICMAC-FAHP methodology for modelling and ranking of the significant degree of enablers in LO relationships in this Area. This integrated approach, which combined FISM-FMICMAC diagraph and FAHP ranking, would help managers to control the efforts and risks of the enablers better than ever before. It is sure that the operation cost will be minimized while the effectiveness in Logistics performance can be improved as high as possible.

\section{CONCLUSION}

For looking for the main factors influencing LO relationship between Shippers and LSP, fourteen factors are considered by collecting experts' opinion and constructed pair-wise comparison matrices under fuzzy linguistic and Scaling of these LVs is done by Trapezoidal fuzzy conversion. This paper which is based on the understanding of the LO relationship in practice, has concluded the significant degree of the enablers in developing the LO relationship among the partners in Mekong Delta Rice SuC. It is resulted that 10 out of 14 enablers have significantly influenced upon the LO relationship with specific global weights on each enabler. FISM-FMICMAC provide an insight overview of enablers of sustainable LO relationships by developing and categorizing. FAHP has been integrated to know the importance of each enabler. The development of the integrated FISMFMICMAC-FAHP method under the trapezoidal fuzzy number in assessing the importance and finding the specific impact weights of the factors on the LO relationship for the Rice $\mathrm{SuC}$ also contributes to enrich the literature on the factbased approach in understanding logistics activities for the rice supply chain.
The results of this paper create a highly practical scientific basis for managers of rice companies in the Mekong Delta to understand the possibility of developing a sustainable LO relationship from which can form more effective solutions for logistics activities. In addition, understanding the key character of the LO relationship will be an extremely important input in decision-making regarding the adjustment of the structure of this activity to business managers, which helps their businesses minimize costs incurred, thus minimizing risks in logistics-related activities.

Finally, by the method that we have framed, this paper can be extended to the other fields besides the logistics of the other supply chains. With other supply chains, to build and maintain LO relationships, managers can use parts of our research results when their company's products have similar characteristics. Meanwhile, the most significant difference when applied to other fields is the specific expertise of the experts and the understanding of the members to the specific nature of research field. Since then, the results of this paper bring more value in practice besides the scientific content that the paper brings.

Limitations and scope for future work

In this paper, only fourteen-variables are limited for modeling the LO relationship. More number of enablers influencing LO relationship should be added to develop FISM for enriching the dynamic suitability to other fields instead of LO relationships, which help to enhance the enterprises' effectiveness. Therefore, developing a more rigorous model with the combination various types of FISM has been proposed for future research.

Although the enablers are identified from reputed journal and industry experts of logistics industry and the actual practitioners and FISM-FMICMAC-FAHP methodology is established, the nature of this study is partly subjective judgements. The subjectivity is mentioned which is the indepth interview process with experts to identify 14 groups of factors affecting the LO relationship before we conduct a survey on the required samples for the next stages this paper. The future study should be expanded to identifying most significant enablers in different industries of sectors in Vietnam by various methodologies and approaches. Moreover, further MCDM techniques liked ANP have also been used for complementing the statistical validation of the hypothetical model in the future study.

Finally, the fuzzy type II approach [13] should be considered for counting the second-stage ambiguity to narrow the uncertainty in the LO relationships analysis.

\section{ACKNOWLEDGEMENT}

This work is partly supported by the research project No. ĐHFPT/2020/02 granted by FPT University.

Graduate student Nguyen Thang Loi was funded by Vingroup Joint Stock Company and supported by the Domestic Master/ $\mathrm{PhD}$ Scholarship Programme of Vingroup Innovation Foundation (VINIF), Vingroup Big Data Institute (VINBIGDATA), code VINIF.2020.TS.26 


\section{REFERENCES}

[1] Ges-kualalumpur 2013, The process and advantages of the signed trade agreements of vietnam, retrieved from https://www.geskualalumpur2013.org/ngoai-giao/cachiep-dinh-thuong-mai-viet-nam-da-ky-ket-qua-trinhva-loi-the/ (accessed on september 12, 2018), 2018.

[2] Ministry of Industry and Trade of Vietnam, Vietnam Logistics report 2017, Logistics: from planning to action, industry and trade publisher, Vietnam: Hanoi, 2017.

[3] Evangelista, p., r. Mogre, a. Perego, a. Raspagliesi, and e. Sweeney, "A survey-based analysis of it adoption and 3PLs" performance.", Supply chain management: an international journal, 17 (2), pp. 172-186, 2012.

[4] Tsai, m. C., k. H. Lai, a. E. Lloyd, and h. J. Lin, "The dark side of logistics outsourcing - unraveling the Potential risks leading to failed relationships.", Transportation research part e: logistics and transportation, Review 48 (1), pp. 178-189, 2012.

[5] Chu, Z., Wang, Q. and Lado, A.A., "Customer orientation, relationship quality, and performance: The third-party logistics provider's perspective", The International Journal of Logistics Management, Vol. 27 No. 3, pp. 738-754. 2016.

[6] Sangam, v. K., "Global logistics outsourcing trends: challenges in managing 3pl relationship." Research Paper. Palmerston north: Massey University, 2015.

[7] Kumar, p., and r. K. Singh, "A fuzzy ahp and topsis methodology to evaluate $3 \mathrm{pl}$ in a supply chain.", Journal of modelling in management, 7 (3), pp. 287-303, 2012.

[8] Liu, Chiung-Lin \& Lyons, Andrew, "An analysis of thirdparty logistics performance and service provision", Transportation Research Part E: Logistics and Transportation Review. 47. 547-570, 2011.

[9] Jayaram, j., and k. C. Tan, "Supply chain integration with third-party logistics providers." International Journal of production economics, 125 (2), pp. 262-271, 2010.

[10] Lam, j. S. L., and j. Dai, "Developing supply chain security design of logistics service providers: An Analytical Network process-quality function deployment approach." International journal of physical distribution \& Logistics management, 45 (7), pp. 674-690, 2015.

[11] König, a., and s. Spinler, "The effect of logistics outsourcing on the supply chain vulnerability of shippers: Development of a conceptual risk management framework." The international journal of logistics management, 27 (1), pp. 122-141, 2016.

[12] Ireland, Ron and Robert Bruce, "CPFR: Only the Beginning of Collaboration,", Supply Chain Management Review, Vol. 4, No. 4, pp. 80-88, 2020.

[13] M.N. Qureshi, Dinesh Kumar, Pradeep Kumar. An integrated model to identify and classify the key criteria and their role in the assessment of 3PL services providers. Asia Pacific Journal of Marketing and Logistics, 20:2, pp. 227-249, 2008.

[14] Magutu, P.O., Nyamwange, S.O. \& Kaptonge G.K, "Business process reengineering for competitive advantage", African journal of business and management, vol.1, pp. 16, 2010.

[15] Ragab, A, "Impact of business process reengineering (BPR) on organizational performance", Harvard Business School, 2009.

[16] Queiroz, M.M., Wanba, S.F. "Blockchain Adoption Challenges in Supply Chain: An Empirical Investigation of The Main Drivers in India and the USA", Int. J. Inf. Manage, 46, pp. 70-82, 2019.

[17] Yuan, Y., Chu, Z., Lai, F., \& Wu, H. "The impact of transaction attributes on logistics outsourcing success: a moderated mediation model", International journal of production economics, 219, pp. 54-65. 2020.

[18] Shou, Y., J. Shao, and A. Chen, "Relational Resources and Performance of Chinese Third-Party Logistics Providers, The Mdediating Role of Innovation Capability." International Journal of Physitical Distribtuion \& Logistics Management, 47 (9), pp. 864 883, 2017.

[19] Liu, X., K. Zhang, B. Chen, J. Zhou, and L. Miao. "Analysis of Logitics Service Supply Chain for the One Belt nd One Road Initiative of China." Transportation Research Part E: Logistics and Transportation Review, 117, pp. 23-39, 2018.

[20] Gu, Flora F., Kineta Hung, and David K. Tse, "When Does Guanxi Matter? Issues of Capitalization and its Dark Sides," Journal of Marketing, Vol. 72, No. 3, pp. 12-28, 2008.

[21] Chen, H., E. James, J. Zemanek, E. S. Mai, and Y. Tien. "Relationship Flexibility in a 3PL Context: Impacts of Network Embeddedness, Guanxi, and Explicit Contract." Journal of Marketing Channels, 22 (4), pp. 253-264, 2015.

[22] Burt, Ronald S, "The Contingent Value of Social Capital," Administrative Science Quarterly, Vol. 42, No. 2, pp. 339-365, 1997.

[23] Cai, S., Jun, M. and Yang, Z., "Implementing supply chain information integration in China: The role of institutional forces and trust", Journal of Operations Management, Vol. 28 No.3, pp.257-268, 2010.

[24] Klein, R. "Customization and Real Time Information Access in Integrated eBusiness Supply Chain Relationships." Journal of Operations Management, 25 (6): pp. 1366-1381, 2007.

[25] Ghosh, A., and J. Fedorowicz. "The Role of Trust in Supply Chain Governance." Business Process Management Journal, 14 (4): 453-470, 2008.

[26] Hofenk, D., R. Schipper, J. Semeijn, and C. Gelderman, "The Influence of Contractual and Relational Factors on the Effectiveness of Third-Party Logistics Relationships." Journal of Purchasing \& Supply Management, 17 (3), pp. 167-175, 2011.

[27] Gao, H., J. Yang, H. Yin, and Z. Ma, "The Impact of Partner Simiarity on Alliance Management Capabillity, Stability and Performance, Empirical Evidence of Horizontal Logistics Alliance in China." International Journal of Phystical Distribution \& Logistics Management, 47 (9), pp. 906-926, 2017.

[28] G. Tejpal, R. K. Garg and A. Sachdeva, "Factor analysis of rational trust among supply chain partners in Indian 
industries," 2013 IEEE International Conference on Industrial Engineering and Engineering Management, Bangkok, Thailand, pp. 915-918. 2013

[29] Yuan, Yang, Feng, Bo; Lai, Fujun, Collins, Brian J., "The role of trust, commitment, and learning orientation on logistic service effectiveness". Journal of Business Research, 93(), 37-50. 2018.

[30] Huo, B., C. Liu, M. Kang, and X. Zhao, "The Impact of Dependence and Relationship Commitement on Logistics Outsourcing, Empirical Evidence from Greater China." International Journal of Physica Distribution \& Logistics Management, 45 (9/10), pp. 887-912, 2015.

[31] Hofstede, G., G. J. Hofstede, and M. Minkov, Cultures and Organisations. Software of the Mind: Intercultural Cooperation and Its Importance for Survival. 3rd ed. New York: McGraw-Hill, 2010.

[32] Hutzschenreuter, Thomas \& Voll, Johannes \& Verbeke, Alain, "The Impact of Added Cultural Distance and Cultural Diversity on International Expansion Patterns: A Penrosean Perspective". Journal of Management Studies. 48. 305-329, 2011.

[33] Gooris, J., and C. Peeters, "Home-Host Country Distance in Offshore Governance Choices." Journal of International Management, 20 (1), pp. 73-86, 2014.

[34] Schuetz, S., Venkatesh., V., Blockchain, adoption, and financial inclusion in India: Research opportunities. Int. J. Inf. Manage, 2019.

[35] Dai, J., Chan, H.K., Yee, R.W.Y., Examining moderating effect of organizational culture on the relationship between market pressure and corporate environment strategy. Ind. Mark. Manage, 74, pp. 227-236, 2018.

[36] Dubey, R., Gunasekaran, A., Chide, S.J., Roubaud, Dd., Wamba, S.F., Giannakis, M, Foropon, C., Big data analytics and organizational culture as complements to swift trust and collaborative performance in the humanitarian supply chain. Int. J. Prod. Econ, 210, pp. 120-136, 2019.

[37] Ellinger, Alexander E., David J. Ketchen, G. Tomas L. Hult, Aye Banu Elmada, and R. Glenn Richey, Jr., "Market-Orientation, Employee Development Practices and Performance," Industrial Marketing Management, Vol. 37, No. 4, pp. 353-366, 2008.

[38] Hsiao, H. I., Kemp, R. G., Van der Vorst, J. G., \& Omta, S. O. A classification of logistic outsourcing levels and their impact on service performance: Evidence from the food processing industry. International journal of production economics, 124(1), pp. 75-86, 2010.

[39] Thai, V. V., Logistics service quality: Conceptual model and empirical evidence. International Journal of Logistics: Research and Applications, 16(2), pp. 144131, 2013.

[40] Arvis, J.-F., Ojala, L., Wiederer, C., shepgerd, B., Rai, A., Dairabayeva, K., et al. Connecting to compete 2018: Trade logistics in the global economy: The logistics performance index and its indicators. New York: World Bank, 2018.

[[41] Williamson, O.E. "Outsourcing: Transaction Cost Economics and Supply Chain Management,', Journal of Supply Chain Management, (44:2), pp. 5-16, 2018.
[42] Daugherty, M. P., Domenico Bosco, and R. P. P. Almeida, "Temperature mediates vector transmission efficiency: inoculum supply and plant infection dynamics." Annals of applied biology, 155.3: 361-369, 2009.

[43] Marcus Wallenburg, C., Cahill, D.L., Goldsby, T.J. and Knemeyer, A.M.,"Logistics outsourcing performance and loyalty behavior: Comparisons between Germany and the United States", International Journal of Physical Distribution \& Logistics Management, Vol. 40 No. 7, pp. 579-602, 2010.

[44] Mothilal, S., Gunasekaran, A., Nachiappan, S. P., \& Jayaram, J., "Key success factors and their performance implications in the Indian third-party logistics (3PL) industry", International Journal of Production Research, 50(9), 2407-2422. 2012.

[45] Karia, N., \& Wong, C. Y., "The impact of logistics resources on the performance of Malaysian logistics service providers", Production Planning \& Control, 24(7), 589-606, 2013.

[46] Zailani, Suhaiza \& Iranmanesh, Mohammad \& Aziz, Azmin \& Kanapathy, Kanagi, "Halal logistics opportunities and challenges". Journal of Islamic Marketing, 8, 2017.

[47] Sanders, N. R., Locke, A., Moore, C. B., \& Autry, C. W., "A multidimensional framework for understanding outsourcing arrangements", Journal of Supply Chain Management, 43(4), 3-15, 2007.

[48] Sinkovics, R. R., R. J. B. Jean, A. S. Roath, and S. T. Cavusgil, "Does IT Integration Really Enhance Supplier Responsiveness in Global Supply Chains?" Management International Review, 51 (2), pp. 193-212, 2011.

[49] Chang, S.E., Chen, Y.-C, Lu, M.-F., Supply chain reengineering using blockchain technology: A case of smart contract-based tracking. Technol. Forecast. Soc.Chang, 144, pp. 1-11, 2019.

[50] Zhao, X., and Q. Tang, "Analysis and Strategy of the Chinese Logistics Cost Reduction." International Journal of Business \& Management, 4 (4), pp. 188-191, 2009.

[51] Large, R. O., N. Kramer, and R. K. Hartmann, "Customer-specific Adaptation by Providers and Their Perception of 3PL-relationship Success.” International Journal of Physical Distribution \& Logistics Management, 41 (9), pp. 822-838, 2011.

[52] Marchet, G., M. Melacini, C. Sassi, and E. Tappia, "Assessing Efficiency and Innovation in the 3PL Industry: An Empirical Analysis." International Journal of Logistics Research and Applications, pp. 1-20, 2016.

[53] Rajesh, R., S. Pugazhendhi, K. Ganesh, D. Yves, S. C. Lenny Koh, and C. Muralidharan, "Perceptions of Service Providers and Customers of Key Success Factors of Third-party Logistics Relationships - An Empirical Study." International Journal of Logistics Research and Applications, 14 (4), pp. 221-250, 2011.

[54] Helo, P., Hao, Y., Blockchains in operations and supply chains: A model and reference implementation. Comut. Ind. Eng, 136, pp. 242-251, 2019. 
[55] Esper, Terry L., Brian S. Fugate, and Beth Davis-Sramek, "Logistics Learning Capability: Sustaining the Competitive Advantage Gained through Logistics Leverage," Journal of Business Logistics, Vol. 28, No. 2, pp. 57-81, 2007.

[56] Hald, K. S., \& Mouritsen, J., "The evolution of performance measurement systems in a supply chain: A longitudinal case study on the role of interorganisational factors", International Journal of Production Economics, Vol. 205, pp. 256-271, 2018.

[57] DUC, T. T. H.; LOI, N. T.; BUDDHAKULSOMSIRI, J. Buyback contract in a risk-averse supply chain with a return policy and price dependent demand. International Journal of Logistics Systems and Management, 30.3, pp. 298-329, 2018.

[58] Yilmaz, C., Sezen, B. and Ozdemir, O., "Joint interactive effects of trust and (inter) dependence on relational behaviors in long-term channel dyads", Industrial Marketing Management, Vol. 34 No. 3, pp. 235-48, 2005.

[59] Eric T.G. Wang, Jeffrey C.F. Tai \& Hsiao-Lan Wei, A Virtual Integration Theory of Improved Supply-Chain Performance, Journal of Management Information Systems, 23:2, pp. 41-64, 2006.

[60] Angelis, J. da Silva, R., Blockchain adoption: A value diver perspective. Bus. Horiz, 62 (3), pp. 307-314, 2019.

[61] Nguyen, H.-O., Critical factors in e-business adoption: Evidence from Australian transport and logistics companies. Int. J. Prod. Econ, 146 (1), pp. 300-312, 2013.

[62] Montecchi, M., Plangger, K., Etter, M., It's real, trust me! Establishing supply chain provenance using blockchain. Bus. Horizons, 62, pp. 283-293, 2019.

[63] Kim, D., Cavusgil, S. T., \& Calantone, R. J., Information system innovations and supply chain management: Channel relationships and firm performance. Journal of the Academy of Marketing Science, 34(1), pp. 40-54, 2006.

[64] Wu, F., Sinkovics, R. R., Cavusgil, S. T., \& Roath, A. S., Overcoming export manufacturer's dilemma in international expansion. Journal of International Business Studies, 38(2), pp. 283-302, 2007.

[65] Agarwal, R., Croson, R., \& Mahoney, J. T, “The role of incentives and communication in strategic alliances: An experimental investigation", Strategic Management Journal, Vol. 31, No. 4, pp. 413-437, 2010.

[66] Krishnan, R., Geyskens, I., \& Steenkamp, J. B. E, “The effectiveness of contractual and trust-based governance in strategic alliances under behavioral and environmental uncertainty", Strategic Management Journal, Vol. 37, No. 12, pp. 2521-2542, 2016.

[67] Hald, K. S., \& Mouritsen, J., "The evolution of performance measurement systems in a supply chain: A longitudinal case study on the role of interorganisational factors", International Journal of Production Economics, Vol. 205, pp. 256-271, 2018.

[68] Ranjith, V. K., \& Bijuna, C., Outsourcing and Competitive Advantage. International Journal of Research in Commerce and Management, 4, 5, 2013.
[69] Tasie, G., "An exploratory review of total quality managment and organizational performance", International Journal of Business and Law Research, Vol. 4 No. 1, pp. 39-45, 2016.

[70] Flynn, P.J., "U.S. patent application no. 29/025,780" Green, K.W., Inman, R.A., Sower, V.E. and Zelbst, P.J. (2019a), "Impact of JIT, TQM and green supply chain practices on environmental sustainability", Journal of Manufacturing Technology Management, Vol. 30 No. 1, pp. 26-47, 1995.

[71] Green, K.W., Inman, R.A., Sower, V.E. and Zelbst, P.J., "Impact of JIT, TQM and green supply chain practices on environmental sustainability", Journal of Manufacturing Technology Management, Vol. 30 No. 1, pp. 26-47 2019.

[72] Gunasekaran, A., Subramanian, N., \& Papadopoulos, T., "Information technology for competitive advantage within logistics and supply chains: A review", Transportation Research Part E: Logistics and Transportation Review, 99, 14-33, 2017.

[73] Brinch, M., Stentoft, J., Jensen, J.K. and Rajkumar, C., "Practitioners understanding of big data and its applications in supply chain management", The International Journal of Logistics Management, Vol. 29 No. 2, pp. 555-574, 2018.

[74] Belvedere, Valeria, and Alberto Grando, Sustainable operations and supply chain management, John Wiley \& Sons, 2017.

[75] Savitha M T and Dr. Mary George, New Methods for Ranking of TFNs. Advances in Fuzzy Mathematics. Volume 12, Number 5, pp. 1159-1170, 2017.

[76] Dube A, Gawande R, ISM-fuzzy MICMAC approach for analysis of GSCM enablers. Int J Logist Syst Manag, 24(4), pp. 426-451, 2016a.

[77] Yadav, S. and Sharma, A., "Modelling of enablers for maintenance management by ISM method", Industrial Engineering \& Management, Vol. 6 No. 203, pp. 2169 0316, 2017.

[78] Lamba, K. and Singh, S.P., "Modeling big data enablers for operations and supply chain management", International Journal of Logistics Management, Vol. 29 No. 2, pp. 629-658, 2018.

[79] Rana, N.P., Barnard, D.J., Baabdullah, A.M., Rees, D. and Roderick, S., "Exploring barriers of m-commerce adoption in SMEs in the UK: developing a framework using ISM", International Journal of Information Management, Vol. 44, pp. 141-153, 2019.

[80] Mishra, S., Singh, S.P., Johansen, J., Cheng, Y. and Farooq, S., "Evaluating indicators for international manufacturing network under circular economy", Management Decision, Vol. 57 No. 4, pp. 811-839, 2019.

[81] Rajput, S. and Singh, S.P., "Identifying industry 4.0 IoT enablers by integrated PCA-ISM-DEMATEL approach", Management Decision, Vol. 57 No. 8, pp. 1784-1817, 2019.

[82] Yadav, S. and Singh, S.P., "Blockchain critical success factors for sustainable supply chain", Resources, Conservation and Recycling, Vol. 152, 104505, 2020. 
[83] Saaty, Thomas L., Fundamentals of decision making and priority theory with the analytic hierarchy process. Vol. 6. RWS publications, 2000.

[84] Rajak, Dipen \& Kumaraswamidhas, L.A \& Das, Satyabrata, "Experimental analysis to improve energy absorption properties of rectangular metal section subjected to axial loading", Materials Today: Proceedings. 3. 2207-2212, 2016.

[85] Do, QUANG HUNG, JENG-FUNG Chen, and Ho-N. Hsieh, "Trapezoidal fuzzy AHP and fuzzy comprehensive evaluation approaches for evaluating academic library service", WSEAS Transactions on Computers, 14: 607-619, 2015.

[86] Banerjee, Sanhita \& Kumar, Tapan, "Arithmetic Operations on Generalized Trapezoidal Fuzzy Number and its Applications", Turkish Journal of Fuzzy Systems. 3. 1309-1190, 2012.

[87] A. I. Ban and L. Coroianu, "Simplifying the Search for Effective Ranking of Fuzzy Numbers," in IEEE Transactions on Fuzzy Systems, vol. 23, no. 2, pp. 327339, April 2015.

[88] BAL BEŞİKÇİ, Elif \& Kececi, Tuba \& Arslan, Ozcan \& Turan, Osman, “An application of fuzzy-AHP to ship operational energy efficiency measures", Ocean Engineering, 121: 392-402, 2016.

[89] Luo, X., Li, W. \& Zhao, W., "Intuitive distance for intuitionistic fuzzy sets with applications in pattern recognition" Appl Intell, 48, 2792-2808, 2018.

[90] Khatwani, G., Singh, S., Trivedi, A., \& Chauhan, A., "Fuzzy-TISM: A Fuzzy Extension of TISM for Group Decision Making", Global Journal of Flexible Systems Management, 16, 97-112, 2015.

[91] Natasa Prascevic \& Zivojin Prascevic, "Application of fuzzy AHP for ranking and selection of alternatives in construction project management", Journal of Civil Engineering and Management, 23:8, 1123-1135, 2017.

[92] B.L. Golden, "The Analytic hierarchy process: applications and studies", Springer-Verlag, New York, 1989.

[93] Chang, D., "Applications of the extent analysis method on fuzzy AHP”, European Journal of Operational Research, 95: 649-655, 1996.

[94] Zarandi, Mohammad Hossein Fazel, Neda Mohammadhasan, and Susan Bastani, "A Fuzzy RuleBased Expert System for Evaluating Intellectual Capital", Advances in Fuzzy Systems, 7, 20

Table 11. Pairwise comparison in level 2 - Creating Factors Cluster IV

\begin{tabular}{ccccccc}
\hline Enables & SC & CT & TM & ADV & ST & CUL \\
\hline SC & $(1 ; 1 ; 1 ; 1)$ & $(6 ; 6.6 ; 7.5 ; 8)$ & $(1 ; 1 ; 1.5 ; 2)$ & $(1 ; 1 ; 1.5 ; 2)$ & $(8 ; 8.5 ; 9 ; 9)$ & $(6 ; 6.6 ; 7.5 ; 8)$ \\
CT & $(0.125 ; 0.1333 ;$ & $(1 ; 1 ; 1 ; 1)$ & $(1 ; 1 ; 1.5 ; 2)$ & $(8 ; 8.5 ; 9 ; 9)$ & $(1 ; 1 ; 1.5 ; 2)$ & $(1 ; 1 ; 1.5 ; 2)$ \\
& $0.1515 ; 0.1667)$ & & & & & \\
TM & $(0.5 ; 0.6667 ; 1 ; 1)$ & $(0.5 ; 0.6667 ; 1 ; 1)$ & $(1 ; 1 ; 1 ; 1)$ & $(2 ; 2.5 ; 3.5 ; 4)$ & $(1 ; 1 ; 1.5 ; 2)$ & $(1 ; 1 ; 1.5 ; 2)$ \\
ADV & $(0.5 ; 0.6667 ; 1 ; 1)$ & $(0.1111 ; 0.1111 ;$ & $(0.25 ; 0.2857 ;$ & $(1 ; 1 ; 1 ; 1)$ & $(1 ; 1 ; 1.5 ; 2)$ & $(1 ; 1 ; 1.5 ; 2)$ \\
& & $0.1176 ; 0.125)$ & $0.4 ; 0.5)$ & & & \\
ST & $(0.1111 ; 0.1111 ;$ & $(0.5 ; 0.6667 ; 1 ; 1)$ & $(0.5 ; 0.6667 ;$ & $(0.5 ; 0.6667 ;$ & $(1 ; 1 ; 1 ; 1)$ & $(1 ; 1 ; 1.5 ; 2)$ \\
& $0.1176 ; 0.125)$ & & $1 ; 1)$ & $1 ; 1)$ & & \\
CUL & $(0.125 ; 0.1333 ;$ & $(0.5 ; 0.6667 ; 1 ; 1)$ & $(0.5 ; 0.6667 ;$ & $(0.5 ; 0.6667 ;$ & $(0.5 ; 0.6667 ;$ & $(1 ; 1 ; 1 ; 1)$ \\
& $0.1515 ; 0.1667)$ & & $1 ; 1)$ & $1 ; 1)$ & $1 ; 1)$ & \\
\hline
\end{tabular}

Table 12. Pair wise comparison in level 2 - Operating Factors Cluster III

\begin{tabular}{cllll}
\hline Enables & COL & PR & CL & PLC \\
\hline COL & $(1 ; 1 ; 1 ; 1)$ & $(8 ; 8.5 ; 9 ; 9)$ & $(8 ; 8.5 ; 9 ; 9)$ & $(8 ; 8.5 ; 9 ; 9)$ \\
PR & $(0.1111 ; 0.1111 ; 0.1176 ; 0.125)$ & $(1 ; 1 ; 1 ; 1)$ & $(1 ; 1 ; 1.5 ; 2)$ & $(1 ; 1 ; 1.5 ; 2)$ \\
CL & $(0.1111 ; 0.1111 ; 0.1176 ; 0.125)$ & $(0.5 ; 0.6667 ; 1 ; 1)$ & $(1 ; 1 ; 1 ; 1)$ & $(1 ; 1 ; 1.5 ; 2)$ \\
PLC & $(0.1111 ; 0.1111 ; 0.1176 ; 0.125)$ & $(0.5 ; 0.6667 ; 1 ; 1)$ & $(0.5 ; 0.6667 ; 1 ; 1)$ & $(1 ; 1 ; 1 ; 1)$ \\
\hline
\end{tabular}

Table 13 Random index (RI) of random matrices.

\begin{tabular}{llllllll}
\hline $\boldsymbol{n}$ & $\mathbf{3}$ & $\mathbf{4}$ & $\mathbf{5}$ & $\mathbf{6}$ & $\mathbf{7}$ & $\mathbf{8}$ & $\mathbf{9}$ \\
\hline $\boldsymbol{R I}(\boldsymbol{n})$ & 0.58 & 0.9 & 1.12 & 1.24 & 1.32 & 1.41 & 1.45 \\
\hline
\end{tabular}

Source: [138] 
INTERNATIONAL JOURNAL OF CIRCUITS, SYSTEMS AND SIGNAL PROCESSING

Table 14 Ranking of Enablers

\begin{tabular}{cclcccc}
\hline $\begin{array}{c}\text { Stages of } \\
\text { adoption }\end{array}$ & No.s & \multicolumn{1}{c}{ Enablers } & $\begin{array}{c}\text { Normalized } \\
\text { weight }\end{array}$ & $\begin{array}{c}\text { Globa } \\
\text { weight }\end{array}$ & $\begin{array}{c}\text { Ran } \\
\text { k }\end{array}$ \\
\hline & SC & System compliance & 0.3225 & 0.2637 & 1 \\
& CT & Commitment or trust & 0.1757 & 0.1437 & 3 \\
Creating & TM & Top management support & 0.1783 & 0.1458 & 2 \\
Factors & ADV & TQM and JIT supplier added (added distinctive value) & 0.1137 & 0.0929 & 5 \\
$(\mathbf{0 . 8 1 7 7})$ & ST & Standardization & 0.1112 & 0.0909 & 6 \\
& CUL & Culture & 0.0987 & 0.0807 & 7 \\
\cline { 2 - 6 } & COL & Buyer-3PL Collaboration & 0.6098 & 0.1112 & 4 \\
Operating & PR & Guanxi (Personal Relationships) & 0.1567 & 0.0286 & 8 \\
Factors & CL & Contract length & 0.1307 & 0.0238 & 9 \\
$(\mathbf{0 . 1 8 2 3})$ & PLC & 3PL Customer Service Expertise & 0.1028 & 0.0187 & 10 \\
\hline
\end{tabular}

\section{Creative Commons Attribution License 4.0} (Attribution 4.0 International, CC BY 4.0)

This article is published under the terms of the Creative Commons Attribution License 4.0

https://creativecommons.org/licenses/by/4.0/deed.en US 